UM Libraries Depository

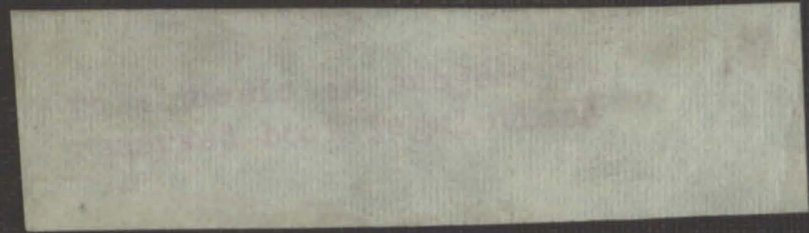




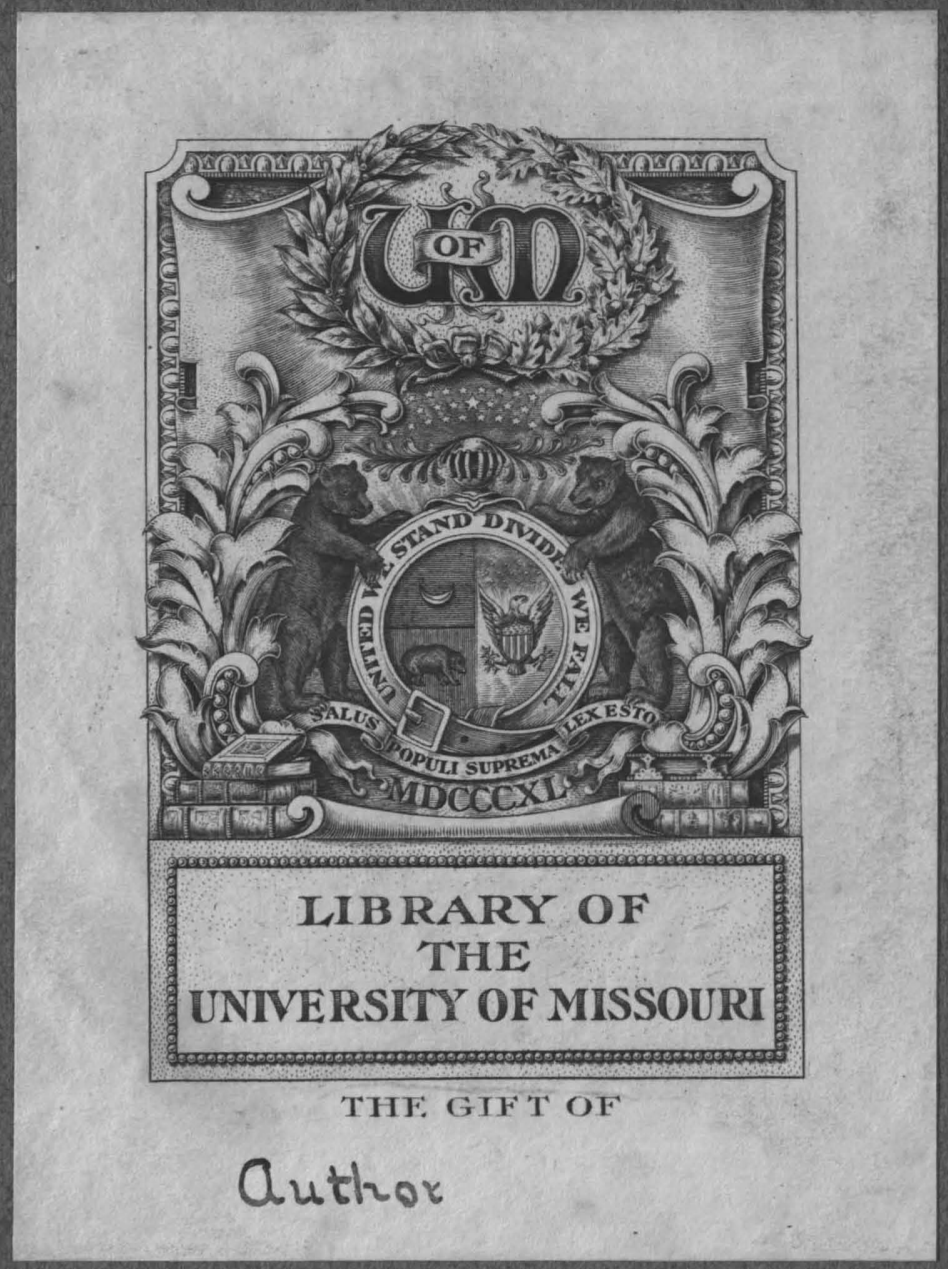

This Thesis Has Been

MICROFILMED

Negative No. T. $\quad 974$ 




THE WITHDRAWAL OF PUPILS FRCM SCHCOL

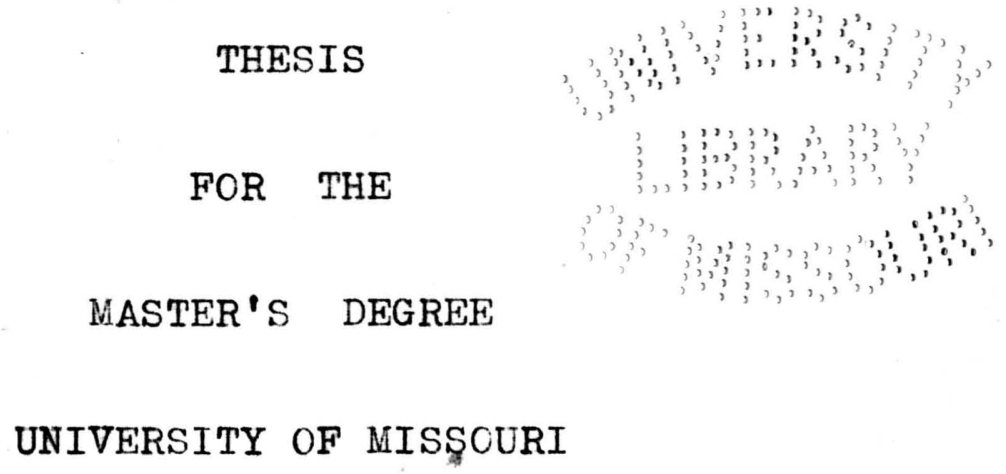

BY

J. W. MAJOR

Affucted Aug1.1906.
f.d. Duniaur. 

$378.7 \mathrm{M71}$

XM28

TABLE OF CONTENTS

Introduction

Page

(a) Attention subject has Received.......... I

(b) Lack of Statistics................... 3

(c) Purpose of the Paper................4

Facts of Withdrawal

(a) At What Age do Pupils Withdraw.........6 6

(b) From What Grades Most Pupils Withdraw.....15

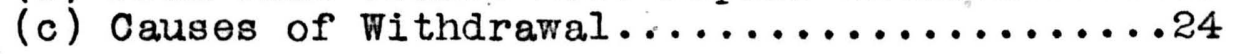

Some Principles Underlying the Course of Study

(a) Some Theories of Education...........4 43

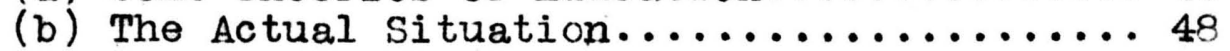

(c) Principles Involved in Omissions........5 51.

A Comparison of a Few Courses of Study

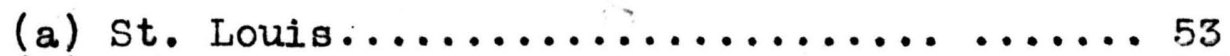

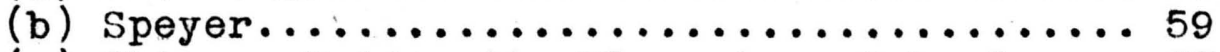

(c) Chicago University Elementary School.....63 63

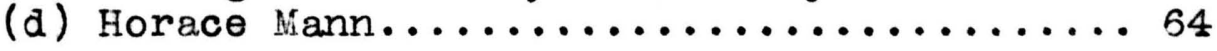

Conclusions.......................66

\section{Di agrams}

I. Attendance by Grades, St.Louis, 1899.... 16

II. " " " " " $1900 \ldots \ldots 17$

III. Causes of Withdrawal by Grdes, Boys.... 28

IV. $" n " n "$ " $"$ Girls... 29 

List of Tables

I. Showing average age of withdrawal ........8 II. Showing ages of withdrawal................... III. $n \quad n \quad n \quad n \ldots \ldots \ldots \ldots \ldots$ IV. School attendance and withdrawals for ages..13 V. Ages of pupils in 4th and 5 th grades.......19 YT. " $n$ n $" n$ n $n$ n ......19 VII. Comparative, St.Louis, Chicago, Boston....20 VIII. Percent of loss for Boonville............21

IX. $n$ n $n$ Carthage............2I

x. " $"$ "Monroe City...........21

XI. " $" n$ "California...........22

XII. Causes of withdrawal.................27

XIII. Withdrawals according to class standing.....30 XIV. $n$ n temperament......3I

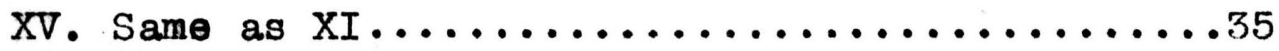
XVI. Percent of withdrawals for causes

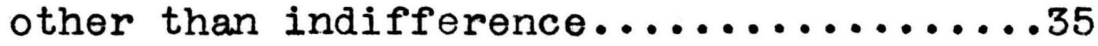

XVII. Percent of withdrawal for indifference.....35 XVIII. Recitation periods per study in St.Louis...56 XIX. Number of hours devoted to the various activities of the Horace Mann School......65

\section{Outlines of Courses of study}

St.Louis Schools..........................54

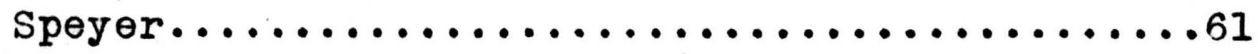





\section{Introduction}

This subject has, porhaps, received more attention and less careful study than any other educational problem. The numerous compulsory school attendance laws, both in Europe and America, testify to the consideration this question has received from lawmakers as well as educators. It is a well known fact that a very small percent of the pupils who enter the public schools-- to say nothing of those who do not enter-- ever complete the elementary course of study, and that a very large percent withdraw so early in the course that they enter the activities of life with scarcely the rudiments of an education. Certainly as long as this is the case, the public school is not fulfilling its mission. Such conditions would be alarming in any country, but in a country like ours, where the people are supposed to rule, the very existence of our free institutions depends upon the intelligence and honesty of our citizens. That the seriousness of the problem is realized is shown by the number of states that have passed compulsory attendance laws. Such laws, however, are based on the assumption that fault is entirely with the parents or the pupils, and that they must be forced to take advantage of opportunities which they do not themselves appreciate. That is an easy way of looking at the problem, and one that is very popular, 

for it frees the school from all blame and puts it all on the side of the pupil, but this is begging the question. What ve wish to find out is, why the schools are not appreciated and why pupils have to be compelled to attend. Is it the fault of the pupil or the parent entirely, or is the school responsible?

For many years a large number of educators have been saying that the course of study is at fault, that we have been offering unpalatable food to the young minds and have thus been driving them out of school. Those who hold this view recognize the futility of forcing children to go to school when the school offers what they have no taste for, and they are seeking for an "enriched" course that will provide the pupil with something worth his while. The introduction of manual training, domestic science, music, drawing, painting, nature study, and physical culture into the course of study speaks eloquently of the efforts of this class of thinkers to solve the problem.

Thus we see that many men have worked on this problem in many ways but they have dealt with it in different phases only, bather than in its entirety. Very few have gathered statistics on this subject to discover why pupils do leave school. Very few have tried to discoter how much blame rests with the pupil, how much the curriculum is at fault, and to what extent 

the teacher is responsible for the large number of withdrawals from school. This seems the proper way to study the question, and the problems suggested seem vital.

The chief reason why so few have dealt with this problem from the stand point of statistics is, probably, that statistics are so very hard to get on this subject. It is comparatively easy to find figures to show at what age and in what grades pupils do drop out of school, but it is extremely difficult to find any accurate record of the reasons why they leave school. Few schools keep any record at all of the causes of withdrawals and in those schools the record is very inaccurately kept. Then, too, it is easier to assume that the fault is with the pupil or with the curriculum. Again, practical teachers are inclined to avoid an investigation which is likely to show that they themselves are somewhat to blame. It is not popular--especially for one in the teaching profession--to criticise teachers. One of the few who have investigated this question prefaced his investigation by discarding at the outset any suggestion that the teachers might be in any way to blame. Reference is to Mr. C. M. Woodward of St. Louis . The teason gives for disregarding the teachers as a factor in the problem is that the St. Louis teachers ate as good as any teachers in the country. His statement is probably true, but since the problem is a general one * Report of Board of Education of St. Louis 1899-1900 Page 26. 

and not confined to st. Louis, the fact that st. Louis teachers are as good as those of any other city does not prove that they are in no way to blame for pupils leaving school.

It is not the purpose of this paper to prove that the teacher is at fault or to prove any pet theory. It is simply an effort to get the truth. However, no claim is made to having solved the problem or even to having reached any absolute results. The value of this paper, if it has any value, is not in what it proves but rather in what it suggests. Every thoughtful Superintendent has studied this question somewhat in his own school, for he can not help but notice the crouded primary and the small seventh and eighth grades.

The first school with which the writer was connected showed an enrollment of over 100 in the primary and less than 45 in the seventh grade. In the next school conditions were even woree; there, the enrollment was 93 in the primary and 26 in the seventh grade. However, upon investigation, conditions were found to be not nearly so bad as these figures indicate, for the school had been growing and whe first grade was much larger than it wa seven years before when thé oeventh grade pupils were in the primary, but after making all due allowances, they were bad enough to call for serious consideration. Thenceforth records of witharawals were kept, giving the reason therefor 

in each case. Still, no attempt was made to systematize or analyze these records until the present study was begun under the direction of Dr. Meriam, of the University of Missouri, and attention called to two articles on the subject; one by Mr. Brooks , of Boston, the other, by Mr. Woodward, of St. Louis. If this study interests any one else in the subject and starts any one else to investigating, it will serve its purpose. No one is asked to accept the donclusions but every one is urged to investigate for himself that from the various investigations some light may be found.

The present study is confined largely to the elementary school, not because of any depreciation of the High School, but because of the freater importance of the Elementary School. A very small percent of our pupils ever reach the High School and of necessity can not until this problem is solbed in regard to the Elementary school. If we wish to strengthen our educational system, we must begin at the bottom.

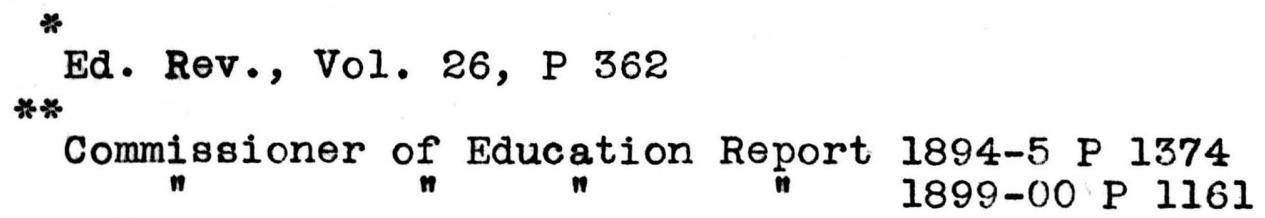



At What Age Do Pupils Leave School

The best statistics on this subject are those compited by Mr. C. M. Woodward in a paper written for The Academy of Science and copied in the report of the Commissioner of Education for $1894-5^{*}$. In this paper Mr. Woodward takes three classes of pupils in St. Louis, three in Chicago, and three in Boston, and traces them from the second grade on through the course. It is necessary to assume that the pupils complete one grade a year so that the pupils who are in the second grade the first year will be in the third grade the second year and so on through the course excepting those who drop ourt along the way. The assumption, as he well knew, is not strictly conpect, for many pupils are held back who do not quit school, but that loss is usually made up by those boing held back from the grade above. In view of this fact the assumption may be accepted. The next thing to take into consideration is the increase in population. The natural increase, or increase by birth, can not affect the case at all but the increase from immigration is a considerable factor. This external gain could only be estimated approximately by taking the total increase in population and subtracting the inctease as shown by the record of births and deaths. Then it had to be determined what part of this 

increase was of school age and how much of it should be added to each grade. These calculations are all based on principles which have been found to be fairly accurate. Thus while the tables can not be aid to be exact, they are as accurate as they can be made. Table I gives figures for enrollment, percent of gain from immigration, actual external gain, possible number belonging, withdrwwals, and the product of the number of withdrawals by the average age of the pupils. In the year 1883-4 the pupils were 8 years old, there were enrolled 7171, the percent of external gaind on the 7835 enrolled the previous yeas was 3,2 , the actual external gain was 250 , the number possible to have been enrolled was 8085 which is obtained by adding the 250 gain to the enrollment of the previous year 7835, the loss was 914 or the difference botween 7171 the actual enrollment and $\phi \varnothing 8085$ the possible enrollment, and the product of 914 by 8 gave 7312 . By adding the figures of the last column and dividing by the total number of withdrawals the average age of pupils leaving school is found. The result as given in this table is 13.3 years. As before said, Mr. Woodward took three classes and in all esentials the other twe tables agree th the one here reproduced.

Tables for Chicago figured in the same wayd show an average of 14.4 years, and tables for Boston, 15.9 years. This shows that conditions differ in 

Table I ( By C. M. Woodward ) *

\begin{tabular}{|c|c|c|c|c|c|c|c|}
\hline $\begin{array}{c}\text { Yoar } \\
1882=83\end{array}$ & $\begin{array}{r}\text { Age } \\
7\end{array}$ & $\begin{array}{l}\text { Enrol } \\
\text { led } \\
7835\end{array}$ & $\mid \begin{array}{l}\% \text { of } \\
\text { ext.g }\end{array}$ & $\mid \begin{array}{l}\text { Amt.of } \\
\text { gain } \\
---\end{array}$ & $\mid \begin{array}{c}\text { Possible } \\
\text { number } \\
7835\end{array}$ & $\begin{array}{l}\text { Withdr } \\
\text { awals } \\
\text { an }\end{array}$ & $\mid \begin{array}{l}\text { Yoar } \\
\text { pupils } \\
-\end{array}$ \\
\hline $1883-84$ & 8 & 7171 & $3 \cdot 2$ & 250 & 8085 & 914 & 7312 \\
\hline $1884-85$ & 9 & 6590 & -0.3 & -22 & 7149 & 559 & 5031 \\
\hline $1885-86$ & 10 & 6301 & -1.0 & -66 & 6524 & 223 & 2230 \\
\hline $1886-87$ & 11 & 5732 & 0.3 & 19 & 6320 & 588 & 6468 \\
\hline $1887-88$ & 12 & 5611 & 0.6 & 34 & 5766 & 155 & 1860 \\
\hline $1888-89$ & 13 & 4279 & $-2 \cdot 1$ & -118 & 5493 & 1214 & 15782 \\
\hline $1889-90$ & 14 & 2944 & 0.9 & 39 & 4318 & 1374 & 19236 \\
\hline $1890-91$ & 15 & 1741 & 1.5 & 44 & 2988 & 1247 & 18705 \\
\hline $1891-92$ & 16 & 1091 & 2.5 & 44 & 1785 & 694 & 11104 \\
\hline $1892-93$ & 17 & 626 & 2.8 & 31 & 1122 & 496 & 8432 \\
\hline $1893-94$ & 18 & 314 & 4.3 & 27 & 653 & 339 & 6102 \\
\hline $1894-95$ & 19 & 117 & -0.1 & 0 & 314 & 197 & 3743 \\
\hline $1895-96$ & 20 & $=-$ & $\ldots$ & $\therefore-$ & 117 & 117 & 2340 \\
\hline
\end{tabular}

$108345+8117=13.3$ Average Age.

The above table is for st. Llouis. Tables figured for Chicago in the same way ahow an average age of 14.5 years and for Boston, 15.9 years.

* Commissioner of Education Report 1899-1900 P 1162 

different localities and are better in older communities. It must be borne in mind, however, that these figures are only approximately correct as they are based on assu-, mptions that are not exact. Nevertreless, as further proof that the figures given do fairly represent conditions, tables II and III are presented. These tables were compiled by Mr. F. Louis Soldan "without regard to the increase of population and yot they agree very largely with those of Mr. Woodward. Note especially the large percent of withdrawals in the eleventh, thirteenth, fourteenth, and fifteenth years.

While it is intended to confine this investigation as much as possible to the elementary grader, one can not but notice in tables II and III the small percent of pupils that reach the High School or the ninth year of the course. One showa 20.9 percent and the other only20.5 percent. Notice also that only 2.5 percent of one class eemained until the last year of the course and only 2.1 percent of the other. Since only $20.9 \%$ remained till the ninth year or High School, the other $79.1 \%$ must have dropped out in the grades. Since out of the $20.9 \%$ that entered the High School only $2.5 \%$ renained to the end, $18.4 \%$ must have dropped out in the High School. When we compare the 18.4\% loss of the High school with the $79.1 \%$ loss of the grades we see the smallness of the High $\phi$ h $\phi$ School problem as compared with that of the Elementary School. However, it is

* Rtp. Board of Ed., St.Louis, p. 39. ( 1894-5) 

Table II Age of Withdrawal of Pupils ( By F. Louis Soldan ) *

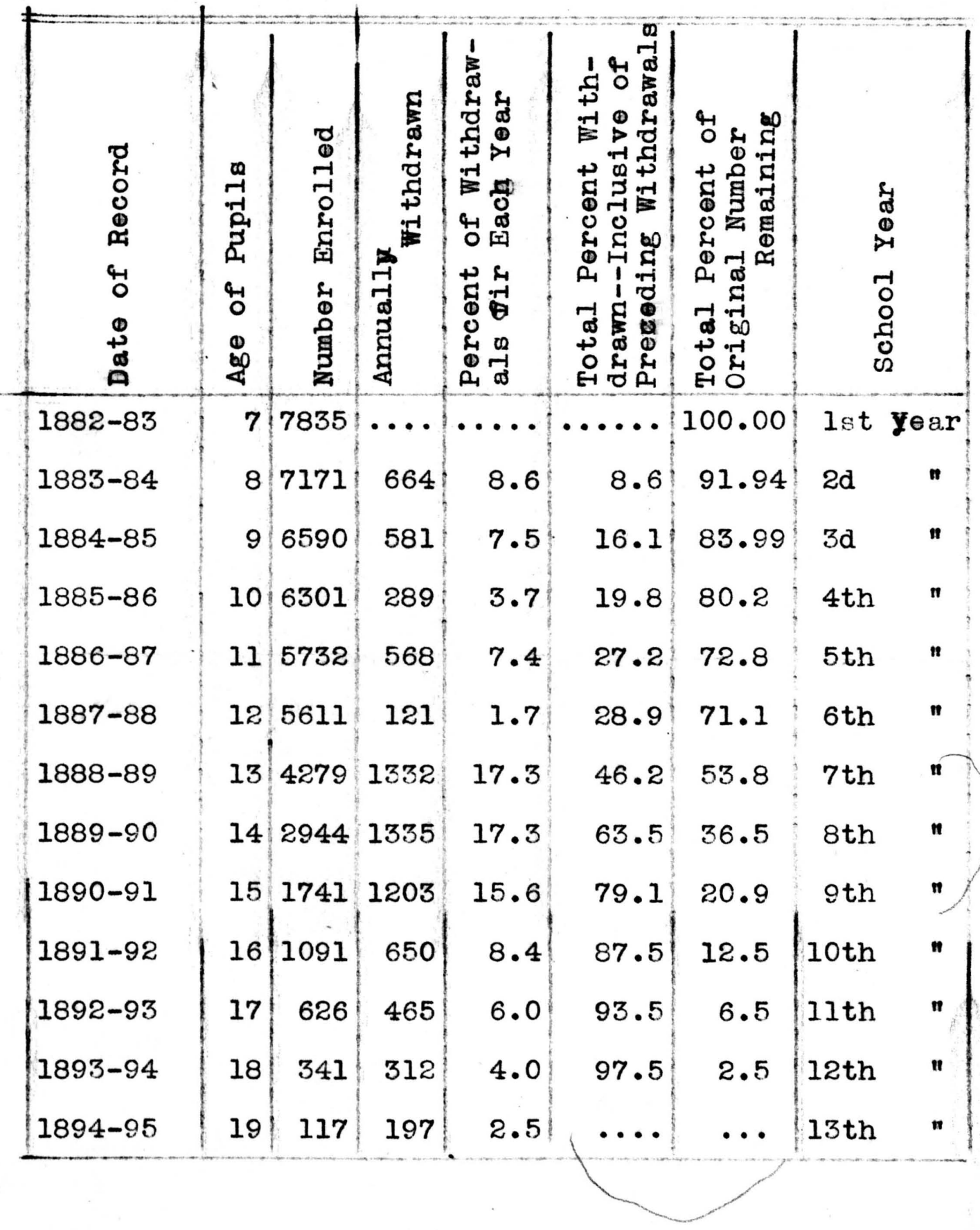

Rep. Board of Ed., St.Louis, 1894-5, p. 39. 

Table III Age of Withdrawal of Pupils ( By F. Louis Soldan )

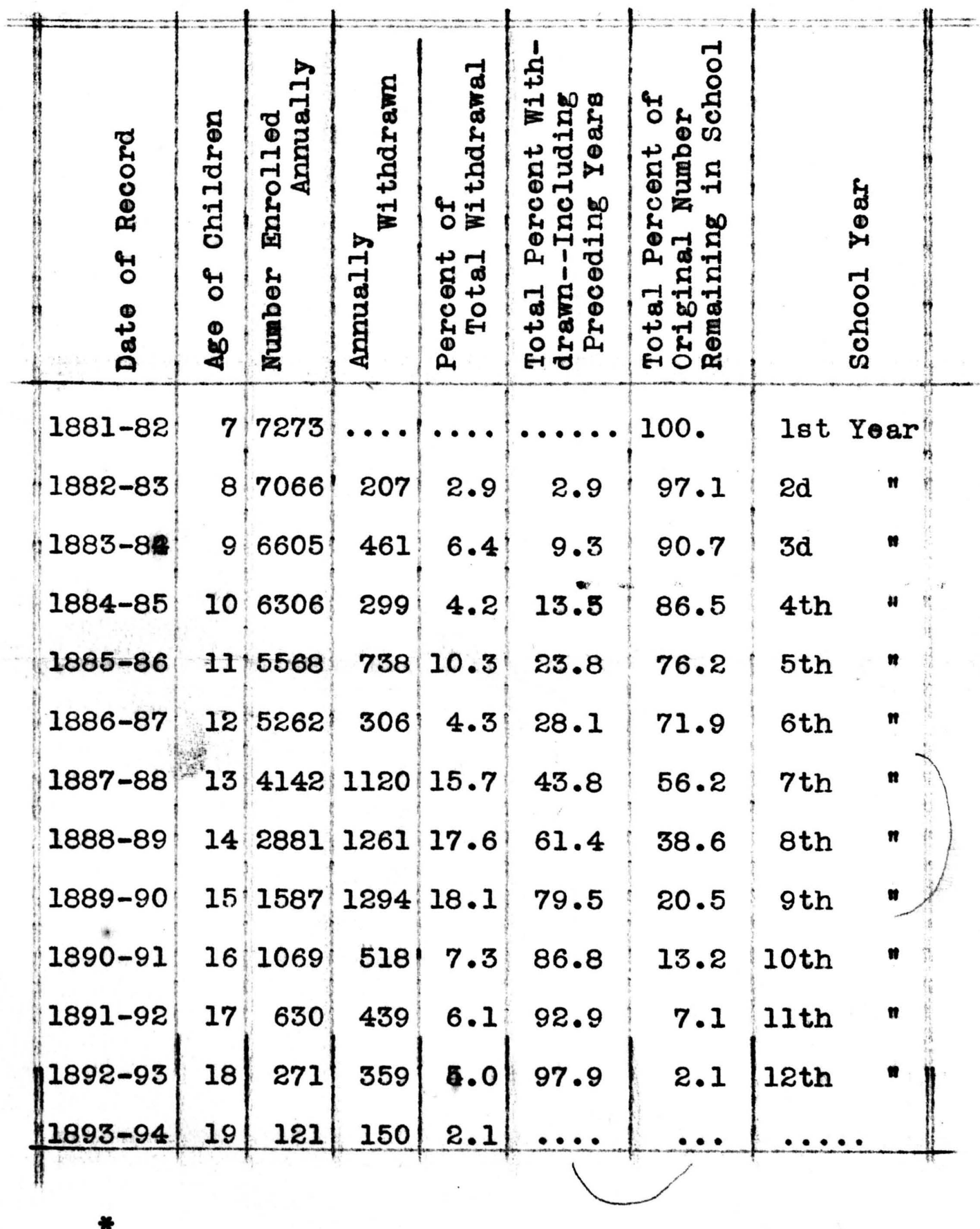

Rep. Board of Ed., St.Louis, 1894-5, p. 39. 

of interest to note that if we compare the $18.4 \%$ loss of the High School with the $20.9 \%$ that enter, we see that $90 \%$ of those who enter the High School drop out whereas the Elementary School loses only 79.1. This shows that the problem affects all of our schools but as only $20.9 \%$ of the pupils reach the High School, the Elementary School is the greatest factor in our educational system and its problems are of paramount importanco. These tables may be objected to on the ground that they are of too old a date to be of much use in considering present conditions. It is true that, considering the assumptiongon which they are based and the time when they were compiled, they do not form a sufficient basis for an indictment against out present school system unless it can be shown that conditions are about the same as they were then. This we are able to do by more recent statistice from the St.Louis schools given by Mr. C. M. Woodward * if the Report of the Board of Education of St.Louis for 1899-1900. Table IV (Page 13) is more recent and more accurate than any we have yet considered but is not worked out in quite the same way as the others. It is more accurate because it is not based on so many assumptions. Actual ages are taken and children are not supposed to be a certain age because they are in a certain grade.

Mr. Woodward calls attention to the fact

* This is also found in the Report of the Commissioner of Education 1899-1900 P 1374. 

Table IV School Attendance and Withdrawals for Certain Ages ( By C. M. Woodward) *

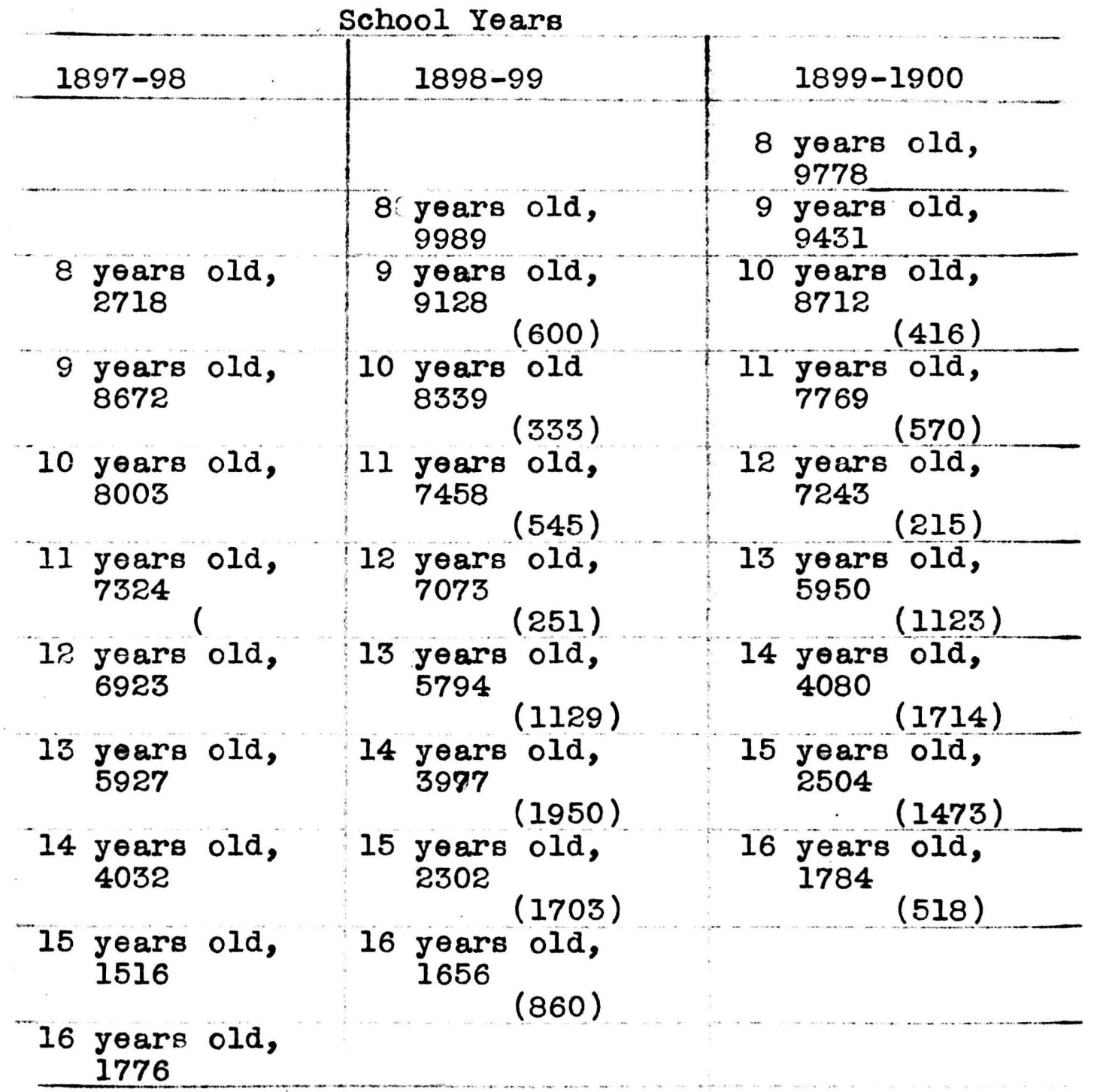

* Report of Commissioner of Education 1899-1900

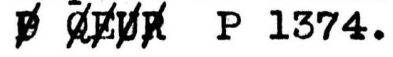



that the number of pupils of a certain age does not vary much from year to yeat but in general shows a little increase, as is readily seen by comparing the number of pupils of any given age in the three columns. By reading down each column of table IV it will be readily seen that after the l2th year the numbers are considerably smaller. This would suggest a large withdrawal of pupils over 12 years of age, but as the pupils who are 12 years old in the first column are not the same pupils as those 13 years old in the same column, it would not be conclusive proof. However, if we read across from one column to the next, we can follow the same pupils and see how many drop out each year. These figures are exact except for the increase from immigration and that would make the number of withdrawals even greater than is shown by the figures of this table. The numbers in parenthesis how how many dropped out of school during the year. of the 6923 who were 12 years old in '97-8, only 5794 appear the next year as 13 years old; this shows a loss of 1129 at 12 years of age. Mr. Woodward says "Let us take those who were twelve, thirteen, and fourteen years old in 1897-8, and see what has become of them. Their numbers aggregated 16882 in '97-8. In 1898-9 they were, of course, thirteen, fourteen, and fifteen years old, and they numbered 12073. In'1899-1900 they were foprteen, fifteen, and sixteen years old, and they aggregated only 8362 . Here is a loss in two years of 8514 fipladren 

out of 16882, with an average age of fourteen years." These tables seem to prove conclusively that twelve, thirteen, and fourteen are the ages at which most pupils leave school in St.Louis. It may be claimed that St.Louis does not represent conditions elsewhere. The comparative study of St.Louis, Chicago, and Boston made by Mr. Woodward and referred to in the first part of this study shows that conditions in St.Louis and other cities do not differ much, and other statistics to be introduced later seem to indicate that the results reached are general and not local.

From What Grades do Most Pupils Withdraw

Diagrams $\mathbb{E}$ and II ( Pages 16 \& 17 ) show very clearly where the great loss in the st.Louis schools is. The two digrams are given to show the similarity. Mr. Woodward aays, "A glance at either the figures of the bounding curves will show that there is a vast falling off at the end of the fourth grade and again at the end of the fifth grade. In one case, of the 9249 children who were enrolled in the fourth grade, only 3045 appear in the sixth. In the other case, 9134 fell to 3012. In each case more than two-thirds disappeared."

These diagrams seem to show plainly enough that the great loss is in the fourth and fifth grades and, 

Diagram I Showing Attendance by Grades, November, 1899

(By C. M. Woodward, Report of Board of Education of St.Louis, 1899-1900, P. 18)

$1 \mathrm{Gr} .2 \mathrm{Gr} .3 \mathrm{Gr}$. 4Gr. 5Gr. 6Gr. 7Gr. 8Gr. 1H,S. 2H.S.3H.S.4H.S

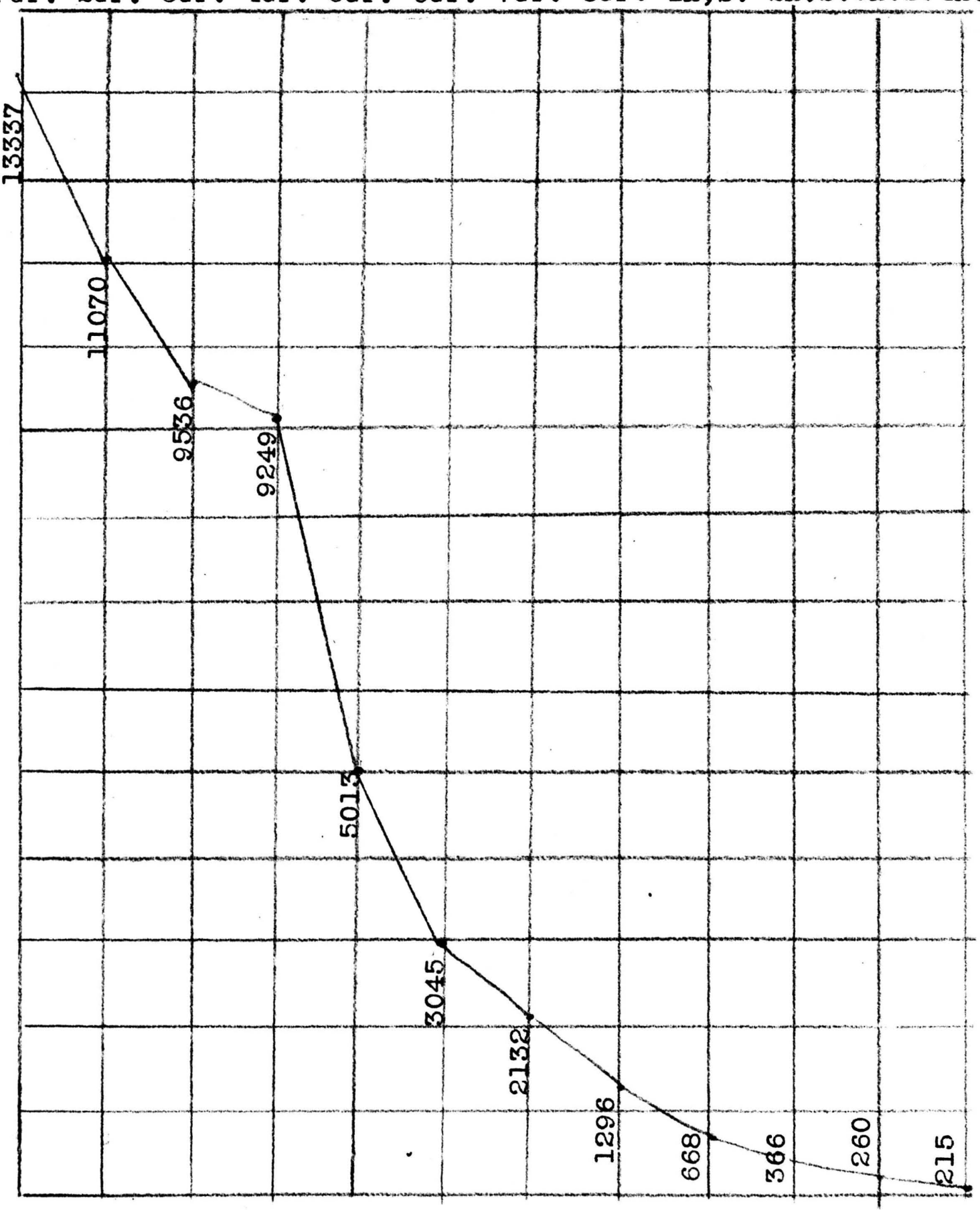

This may be foun in the Report of Commissioner of Education, 1899-1900, P. 1374. 

Diagram II Showing Attendance by Grades, November, 1900

(By C. M. Woodward, Report of Board of Education of St.Louis, 1899-1900, P. 19.)

1Gr. 2Gr. 3Gr. 4Gr. 5Gr. 6Gr. 7Gr. 8Gr. 1H.S. 2H.S. 3H.S.4H.S.

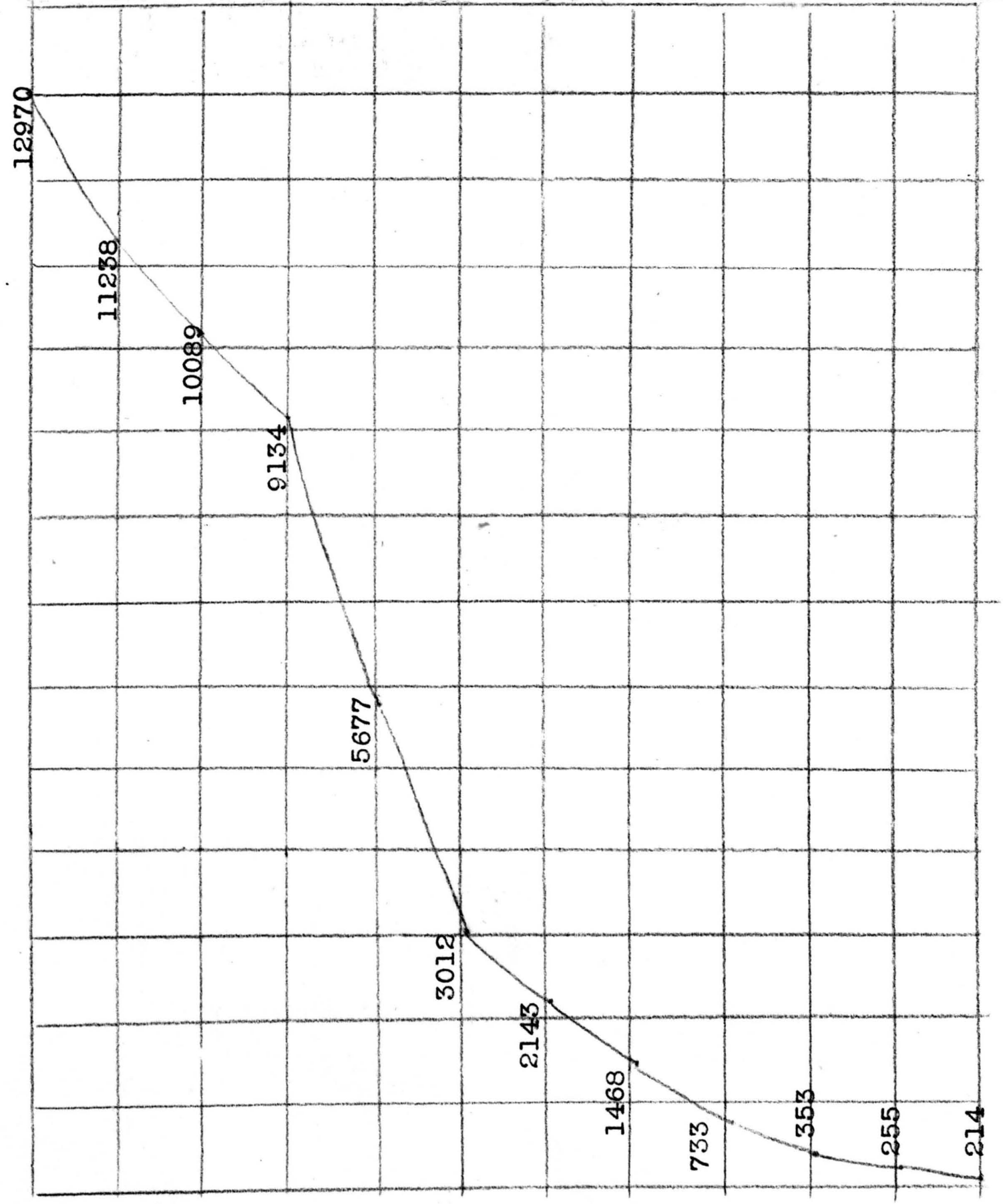

This diagram may be found in the Report of Commissioner of Education, 1899-1900, P. 1374. 

considering the age at which pupils withdraw (13, 14, \& 15), would seem to indicate that pupils who withdraw are usually over age. Pupibs in the fourth and fifth grades would normally be ten and eleven years old, but we found that the largest number of pupils leave school at the ages thirteen, fourteen, and fifteen years, and that they drop out of the fourth and fifth grades. We can not escape the conclusion, then, that these pupils who withdraw are several years above the normal age. This is proven still more conclusively by the next two tables (Page 19). These tables were given by Mr. Woodward to confirm the ones we have just studied and for a more completie analysis of the loss. They show that, while the loss is distributed over all ages, much the greater part is from the older pupils.

Mr, Woodward in commenting on tables $V$ and $V I$
says, "The amount of the loss shown in these two tables is appalling. In spite of free schools in comfortable and attractive buildings, insspite of skillful teachers and expert supervision, nearly six thousand of our boys and girls every year stop going to school, with the district school course of study only about half finished. This is a sad 5tate of things, yet it should be known to every citizen of St.Louis, that every year a vast army of public school boys and girls, who are thirteen and fourteen and fifteen years old, in the middle of 

Table V--Ages of Pupils in the Fourth and Fifth Grades

Fourth Grade in 1899 Fifth Grade in 1900 Loss

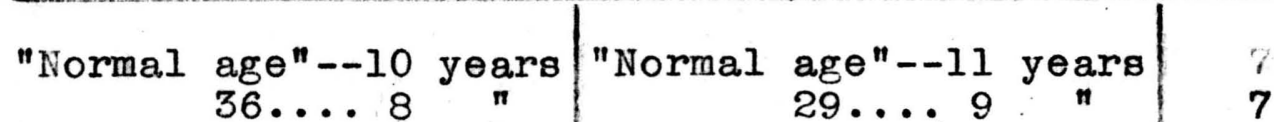

$36 \ldots 8$

$537 \ldots . .9$

$2094 \ldots 10$

$2759 \ldots 11$

$2170 \ldots 12$

$1127 \ldots . .13$

$386 \ldots 14$

$118 \ldots .15$

$15 \ldots 16$

$6 \ldots .17$

Totals 9240

$1 . \ldots 18$

"

$299 \ldots 10$

$1253 \ldots .11$

$1787 \ldots . .12$

$1497 \ldots .13$

$578 \ldots . .14$

$193 \ldots 15$

$38 \ldots .16$

$2 \ldots 17$

$1 \ldots .18$

$\frac{0}{5677} \cdot 19$

\begin{tabular}{l|r}
$n$ & 7 \\
$n$ & 238 \\
$n$ & 841 \\
$"$ & 972 \\
$"$ & 673 \\
$"$ & 549 \\
$n$ & 193 \\
$"$ & 80 \\
$"$ & 13 \\
$"$ & 5 \\
& 3572
\end{tabular}

Table VI--Ages of Pupils in the Fifth and Sixth Grades

Fifth Grade in 1899 Sixth Grade in 1900 Loss

"Norma

\begin{tabular}{|c|c|}
\hline $\begin{array}{r}\text { age-11 } \\
28 \ldots .9 \\
252 \ldots .10 \\
1025 \ldots 11 \\
1603 \ldots 12 \\
1278 \ldots 13 \\
628 \ldots 14 \\
159 \ldots 15 \\
36 \ldots 16 \\
2 \ldots 17 \\
2 \ldots .18\end{array}$ & $\begin{array}{c}\text { year } \\
n \\
n \\
n \\
n \\
n \\
n \\
n \\
n \\
n\end{array}$ \\
\hline
\end{tabular}

Totals 5013

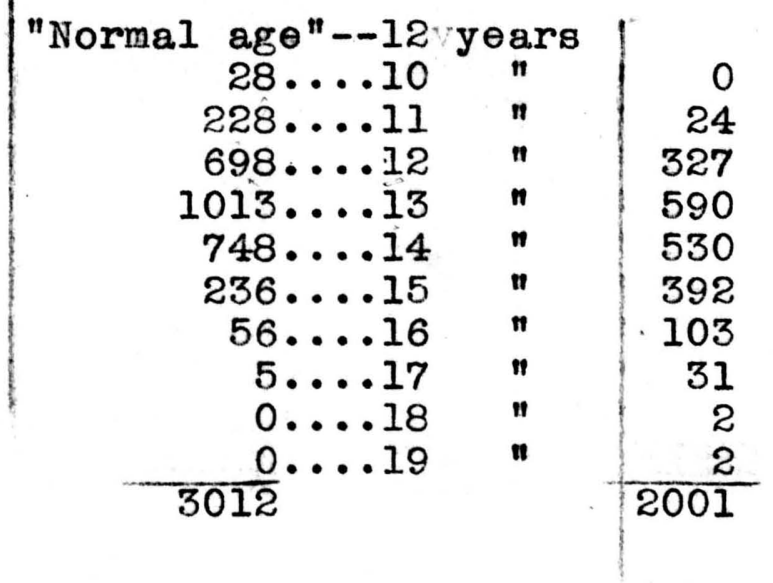

These tables are found in the Report of Board of Education of St.Louis, 1899-1900, P. 20. They show that the withdrawals are largely from the older pupils. 

the district course, for one reason or another, stop going to school. These facts have much the nature of a public calamity, and it is the solemn duty of those in responsible charge of the schools to point out as clearly as possible the probable causes and the most practicable remedies. I am convinced that the causes are in a large measure preventable, and the remedies are in our hands."

We must bear in mind that these figures represent st.Louis and only in a general way indicate conditions elsewhere. A comparative table for the attendance in St.Louis, Chicago, and Boston is here presented. This table is based on the enrollment of the second grade which is represented by $100 \%$.

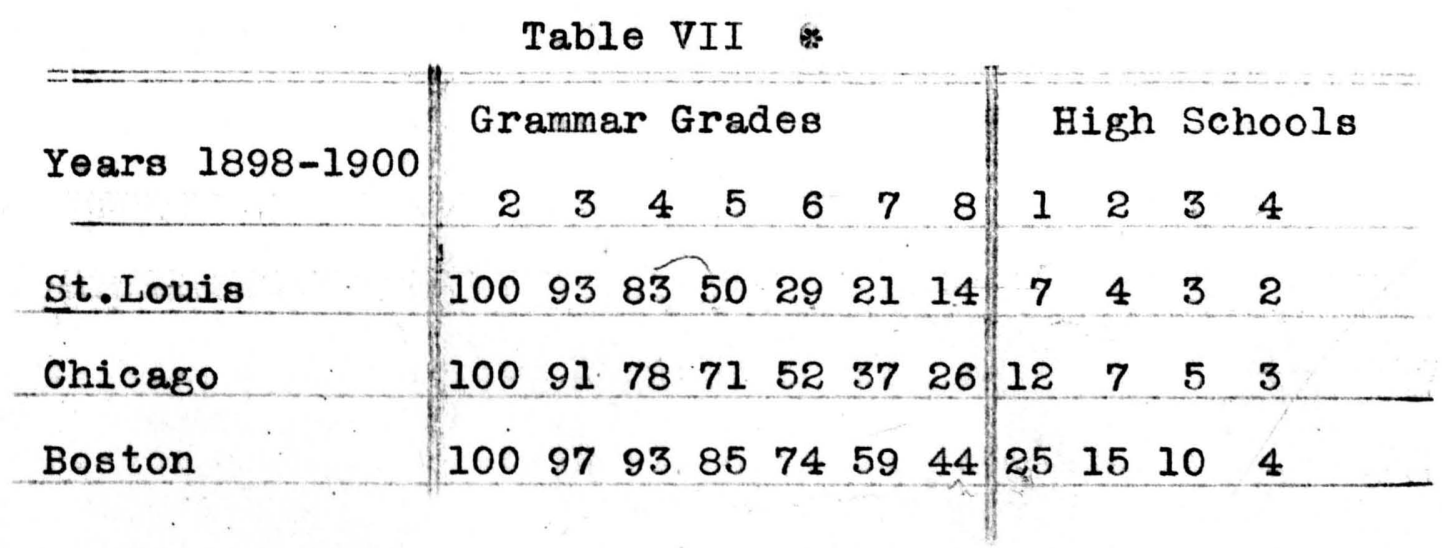

St.Louis has a better record than Chicago up to the fourth grade but falls behind from there on and both are behind Boston. However, in all three we see the same tendency to drop out with ever increasing rapidity after passing the thire grade. We can not expect the records of any two cities to agree exactly because conditions differ. We can not ignore local conditions * Report of Board of Education for St.Louis, 1899-1900,P 22 . 

in any problem.

As might be expected, in the smaller town of the state we see more variations and less uniformity. In tables VIII, IX, $X$, and XI (Pages 22 \& 23) we have some statistics gathered from smaller places. These tables are constructed on a different plan from any we have had; they are comPuted entirely in percents based on the yearly enrollment of the separate grades. For example, in the above table we have Yr.I, Gr.1, 13. This means that 13\% of the pupils who were enrolled in the first grade the first year of this record never appeared in the second grade the following year. The first three of these tables are not very exact because of the way in which they were compiled. The number leaving school was obtained by looking over the records and counting the ones actually dropped. This would seem to be fair but frequently happenis that a pupil quits school one year and comes back the following year and these were not taken into account. This is a very large factor, especially in the lower grades, and probably accounts for the very great loss shown in the first, second, and third grades in the tables under discussion. In collecting the statistics for California, Mo., it was found that a large mumber of pupils were marked dropped several times before they finally disappeared from the records. Unfortunately the statistics for Boonville, Carthage, and Monroe City were not subjected to the same scrutiny. The large percent of loss shown in the seventh and eighth grades of these 

Table VIII-Showing Percent of Loss for Boonville. Gr.1 Gr.2 Gr.3 Gr.4 Gr.5 Gr.6 Gr.7 Gr.8

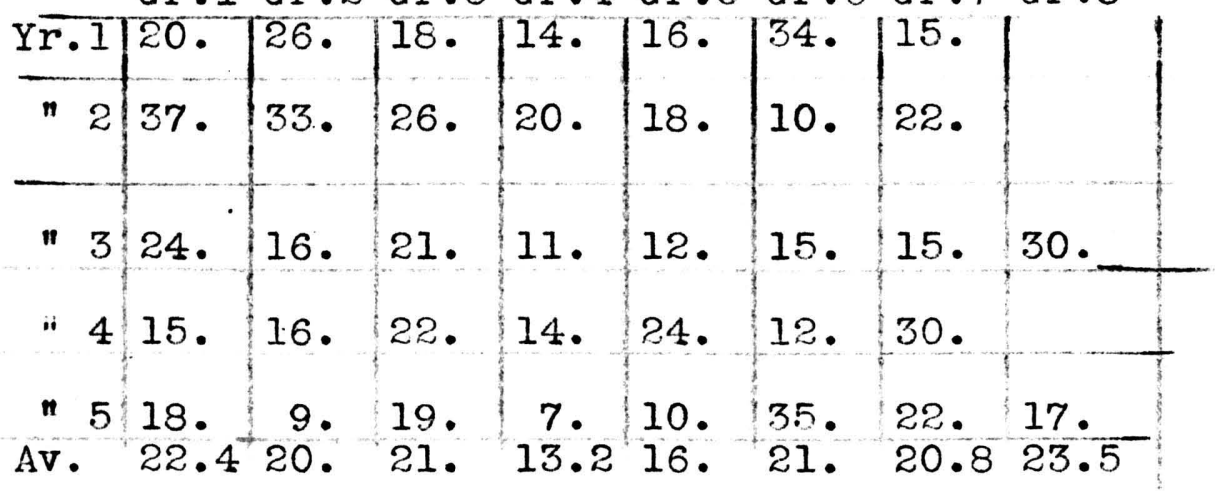

Table IX--Showing Bercent of Loss for Carthage

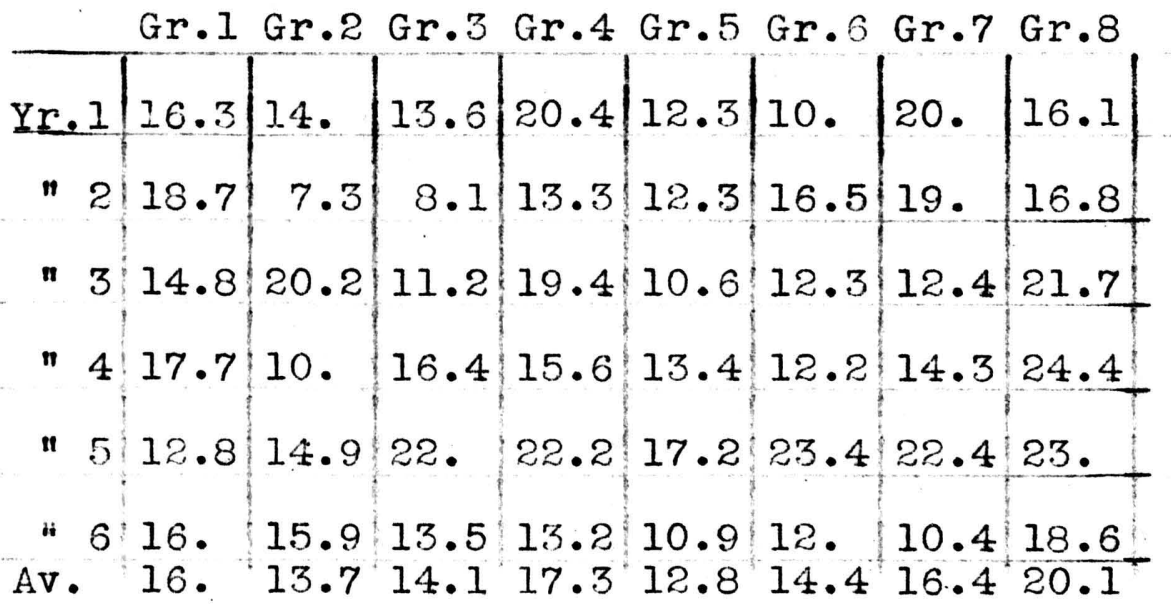

Table X--Showing Percent of Loss for Monroe City

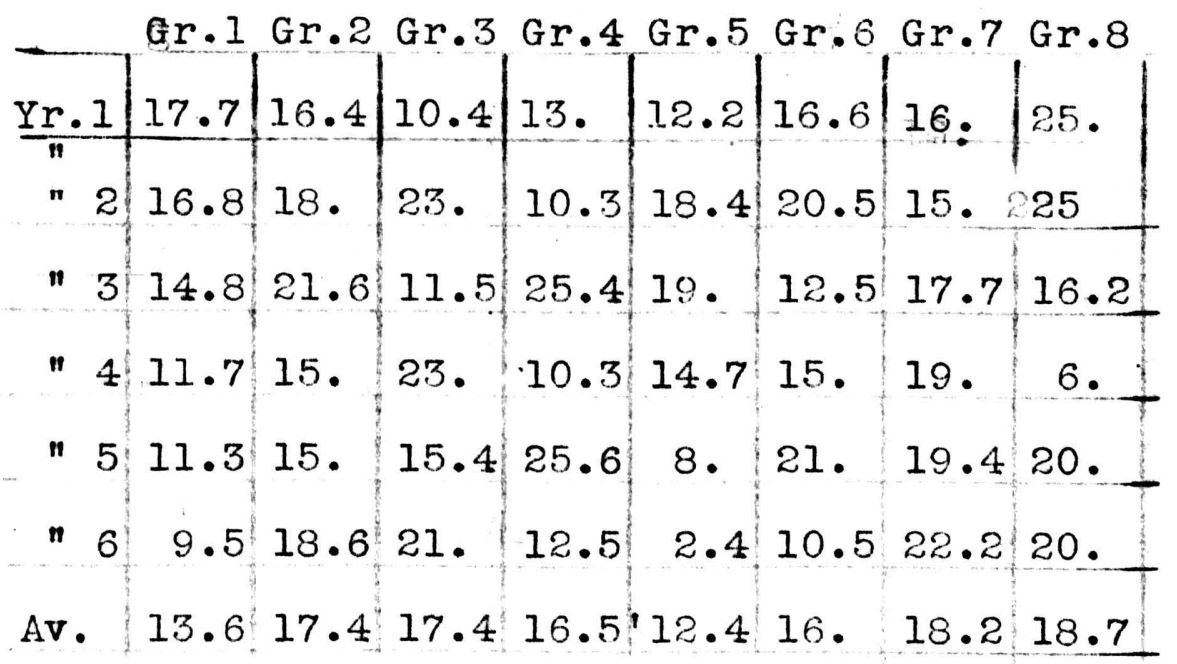



Table XI--Showing Percent of Loss for California

\begin{tabular}{r|c|c|c|c|c|c|c|c|} 
Gr.1 & 13. & 13. & 18. & 20.6 & 30. & 30. & 18. & 17.2 \\
\hline "2 & 16.3 & 15.8 & 20. & 30. & 20.6 & 24.5 & 12. & 27.6 \\
\hline 3 & 8. & 15.2 & 30. & 18. & 5. & 20. & 9. & 20.7 \\
\hline 4 & 18.4 & 14. & 22. & 23. & 30. & 18.4 & 10. & 10.7 \\
\hline 5 & 10.4 & 12.7 & 20. & 33.3 & 25. & 25. & 25. & 0. \\
\hline 6 & 12.5 & 14. & 20. & 13.6 & 20.6 & 14. & 13.5 & 17.2 \\
\hline Av. & 13.2 & 14.1 & 21.6 & 22.4 & 23.8 & 22.5 & 16.2 & 15.5 \\
\hline
\end{tabular}

tables is probably correct, al tho a few in those grades stop to work in the spring and enter again in the fall. We must remember, however that a large percent in the eighth grade represents a very much smaller number of actual pupils than a much smaller percent in the lower grades because the enrollment in the eighth grade is very much smaller than it is in the lower grades. These tables have little uniformity and tend only to show that there is a large dropping out in the lower grades. They mught also seem to indicate that the problem is largely a local one

Note especially the table for California, Mo. ( page 23), because it is accurate. It is not based on any assumptions but was compiled by taking the roll of each grade and finding out from the registers who were droppect permanently. When a pupil was marked dropped, the records were ezplored to see if his name ever reappeared on the register, before he was counted 

among those leaving school. This table shows quite mubler of noticeable exceptions, of which more will be said later; but in general it gives the greatest loss in the third, fourth, fifth, and sixth grades, and is a fair confirmation of what might have beejexpected from the figures given for St.Louis. It is safe to conclude thet the great mass of pupils leave school in the fourth, fifth, and sixth grades and when they are only thirteen, fourteen, or fifteen years of age.

\section{Causes of Withdrawal}

This is the most difficult part of the problem, for causes are hard to discoter. Where conditions are complex, it is well nigh impossible to prove that one fact is the cause of another. The best we can do is to find what seems most likely to be the cause. First consider Mr. Woodward's conclusions based on the tables previously copied from him.

Poverty is the cause most frequently given and is really responsible for some withdrawals, but it is frequently used as a cloak for neglect on the part of the parent or lack of interest on the part of the pupil. Since the loss is chiefly among the older pupils, those who are aboive the normal age and old enough to have finished the course, it can not be attributed to poverty. Some is due to natural dullness but certainly 

that will not account for such a large 10s8. Mr. Woodward aays: "My deliberate conclusion after a careful study of the matter is that the prime causeaffor the abnormal withdrawals are: first, a lack of interest on the part of the pupils; second, a lack on the part of the parents of a just appreciation of the education now offered, and a dissatisfaction that we do not offer instruction and training of a more practical character. The pupils become tired of the work they have in hand, and they see in the grades above them no sufficiently attractive features to invite them. They become discontented and neglectful; failure follows, they get behind, and then they stop."

This lack, or loss of interest on the part of the pupils is partly the fault of the school in not adapting the course of study to the growing powere and tastes of the adolescent mind. The pupil at this age wants to do things and not to spend his time memorizing the printed page.

The great loss at the end of the fourth grade was due to having to buy text-books. Fre日 books were at that time furnished up to and including the fourth grade. At that point the parent was confronted with the nebessity of buying books or taking the child out of school and he frequently did the latter. Free textbooks seem to have improved the attendance as far as 

they were used but had a very bad effect during the remainder of the course. A parent who has been accustomed to free text-books feels aggrieved when called upon to buy books.

That Chicago and Boston each surpassed st. Louis in attendance in accounted for by manual training. At the time the comparison was made both Chicago and Boston had a well established course in manual training and domestic science in the higher grades while St.Lovis had scarcely begun the work.

As Mr. Woodward fails to criticise the teachers, a quotation from Mr. Soldan is admissable. "There is a personal equation in the matter of wi tharawal. The tone of a school, what is some times called 'its popularity', the personal character and magnetism of its principal and corps of teachers frequently has much to do with the relative frequency of withdrawals. There are . schools which naturally attract the child and there are schools which naturally repel it. Efficient; tho genial, discipline is a wonderful agency in keeping a school together. $* * *$ Instruction, too, has an influence on the early withdrawal of children, which is no less potent than that of discipline. Where instruction is lifeless, monotonous, uninteresting, unprofitabie, or unreasonably exacting, it becomes the instinctive tendency of a child to withdraw from school as earty as he is able to prevail on his parents to let him do so. It is the childss Report of Board of Education, St.louis, 1894-95, p 46. 

natural protest against faulty treatment."

Mr. Soldan strikes at one of the most important factors in this problem. The personality of the teacher and the kind of instruction certainly are of vital impor$\operatorname{tanc} \theta$.

Mr. Brooks, of Boston, has perhaps gone into this problem more systematically than any one else. He asked one hundred and eleven superintendents of his acqiaintance to keep a record of the causes of withdrawal and report to him. Twelve hundred reports were received and tabulated as followa.

Table XII--Showing Causes of Withdrawal

\begin{tabular}{|c|c|c|c|c|c|c|}
\hline \multirow[t]{3}{*}{ Causes of Withdrawal } & \multicolumn{6}{|c|}{ Percentages } \\
\hline & \multicolumn{3}{|c|}{ Boys } & \multicolumn{3}{|c|}{ Girls } \\
\hline & $\begin{array}{l}\text { Gra } \\
\text { des }\end{array}$ & $\mathrm{H} . \mathrm{S}$ & $\begin{array}{l}\text { Tot } \\
\text { al }\end{array}$ & $\begin{array}{l}\text { Gra } \\
\text { des }\end{array}$ & $\mathrm{H} . \mathrm{S}$ & Total \\
\hline Ill health & 9 & 5 & 8 & 36 & 38 & 37 \\
\hline To work & 51 & 37 & 46 & 32 & 17 & 26 \\
\hline Desire for activity & 4 & 9 & 5 & 0 & 0 & 0 \\
\hline Indifference & 9 & 12 & 10 & 11 & 14 & 12 \\
\hline Failure in work & 6 & 11 & 7 & 7 & 13 & 9 \\
\hline Home infiuence & 8 & 1 & 6 & 6 & 1 & 4 \\
\hline Truancy & 3 & 4 & 4 & 1 & 0 & 1 \\
\hline Bad conduct & 4 & 2 & 3 & 1 & 1 & 1 \\
\hline To attend other schools & 2 & 4 & 3 & 4 & 7 & 5 \\
\hline Dislike for authority & 2 & 11 & 5 & 1 & 4 & 3 \\
\hline Bad habits & 2 & 3 & 2 & 0 & 0 & 0 \\
\hline Society & 0 & 1 & 1 & 1 & 5 & 2 \\
\hline
\end{tabular}

Ed. Rev., Vol. 26, p. 362 . 

Diagram III--Showing Causes of Withdrawal by Grades

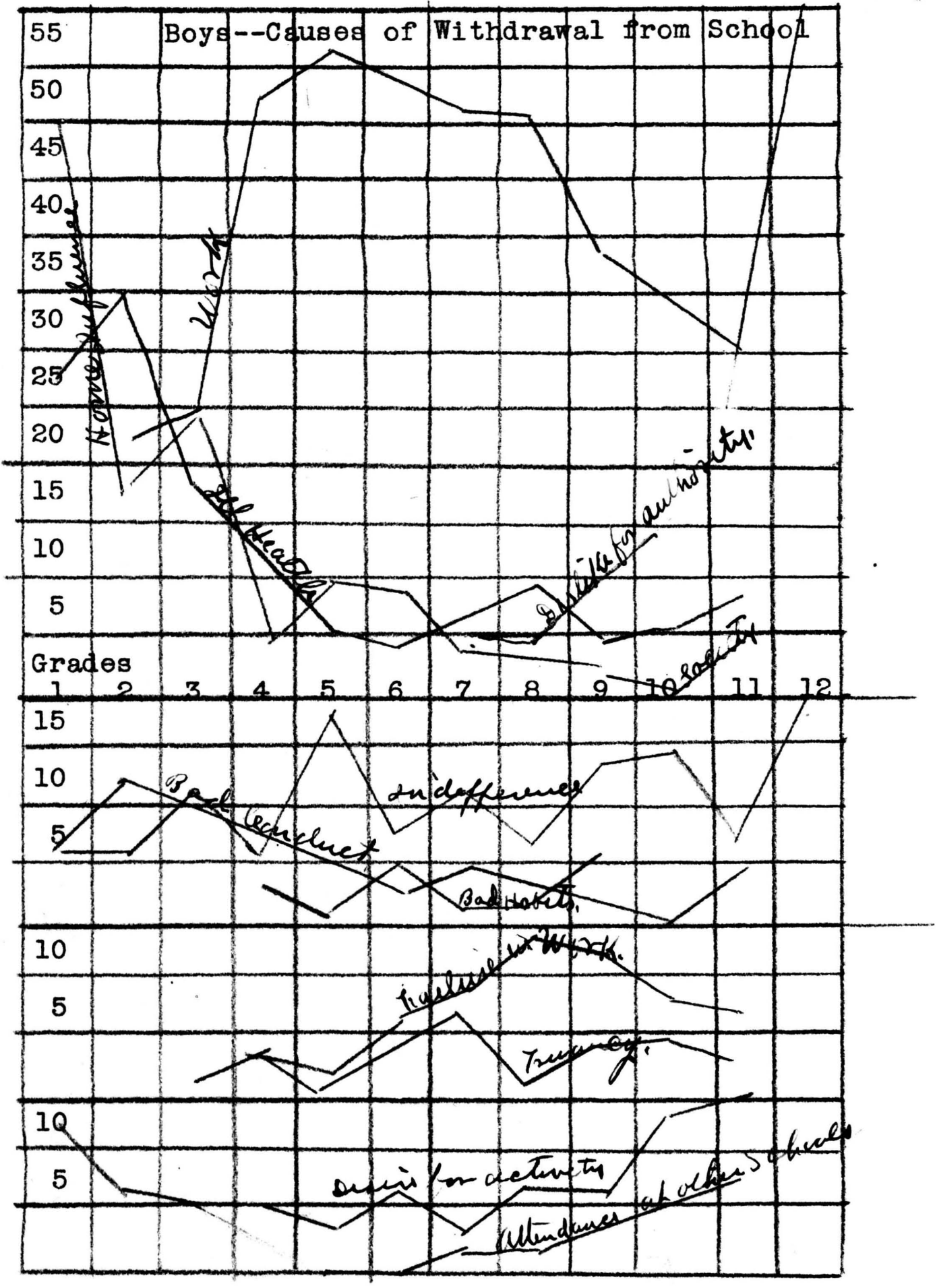



Diagram IV--Showing Causes of Withdrawal by Grades

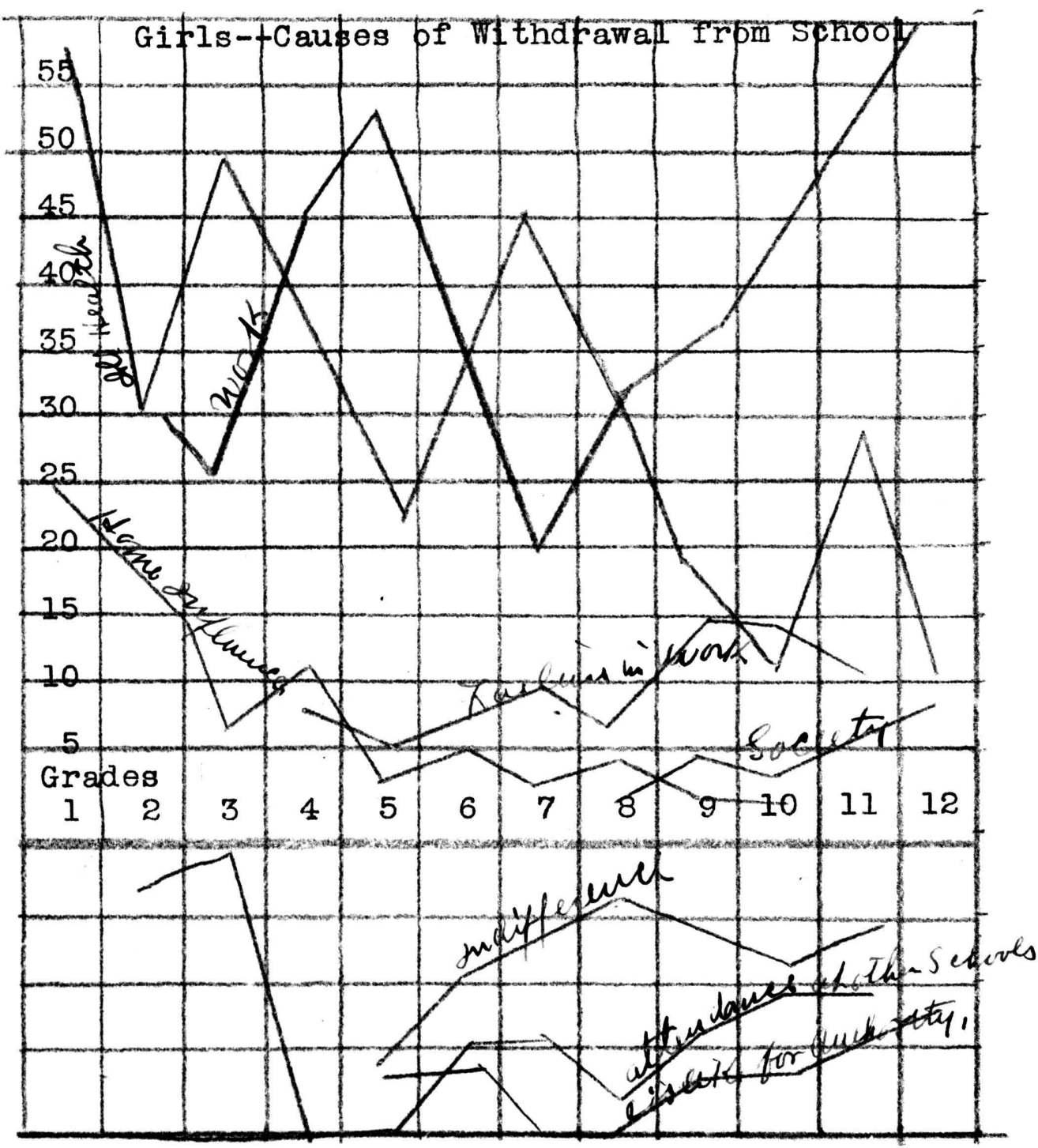

The distribution of these causes through the grades is shown by the diagram copied from Mr. Brooks' paper. To avoid confusion the diagram for boys is divides into four parts with the base line repeated in each case, and the one for girls is divided into two parts. With the exception of work, home influence and ill health are the chief causes of the witharawal of boys in the first three 

grades. Truancy, bad habits, and a desire for activity begin in the fourth grade. In the fifth grade indifference is prominent. The sixth grade has some of all causes. Truancy and failure to pass become prominent in the seventh grade.

With girls, ill health is the chief cause of withdrawals in all grades. Indifference becomes very prominent in the fifth grade and continues to grow until the eighth.

The report on age shows that nearly all the pupils who withdrew were over age. Even those who quit for ill health were above the normal age for their grade. This seems to indicate that age and being behind in the work are important factors in the problem. The average age of boys leaving the third grade was thirteen, or four years above the normal age for that grade, and those who left the third and fourth grades on account of failure to pass it was six years above the normal. Is it any wonder they quit?

\section{By classifying the withdrawals according to} standing in class (dividing the class in quarters) Mr. Brooks obtained the following percents.

Table XII

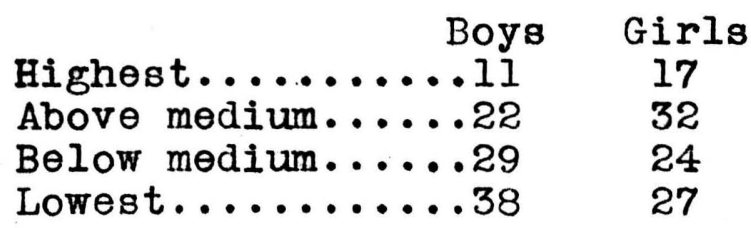

It is interesting to notice the relation of indifference 

to class standing. Since $11 \%$ of all withdrawals were from the highest quarter of the class, we might expect that $11 \%$ of those who left on account of indifference would be from the highest quarter of the class, whereas only $3 \%$ were actually from the better students. In the second quarter where wè might expect $22 \%$, we actially find only 12\%, and in the third quarter we find $26 \%$ instead of $29 \%$, but in the fourth quarter we find $69 \%$ where we expected only 38\%. The chief cause for the withdrawal of the $11 \%$ was sickness. Indifference made the least showing of any.

Classifying the withdrawals according to temperament, the following percentages weee found:

Table XIV

$\begin{array}{lcc} & \begin{array}{c}\text { Boys } \\ 23\end{array} & \begin{array}{c}\text { Girls } \\ 34\end{array} \\ \text { Nervous } & 23 & 37 \\ \text { Above medium } & 32 & \\ \text { Below medium } & 25 & 23 \\ \text { Stolid } & 20 & 6\end{array}$

This shows that nervousness is much more common among girls than among boys. We saw that sickness also was the principal cause for withdrawal among girls. As the nervous pupils are usually among the best in the class, this accounts for the large number withdrawing from the first quarter of the class on account of sickness. Next to sickness, bad conduct and dislike for authority were the most prominent caue日s for the withdrawal among the nervous and above medium. It would seem from this that nervous pupils are frequently driven out 

of schodl by lack of tact on the part of the teacher or principal. Nervous pupios are usually bright and $\theta \theta \theta$ through things in about half the time the stolid ones do; this leaves them spare time and, as they must do something, they get into mischies, are reprimanded, make an impudent reply, and are forced out of achool.

Altho $51 \%$ of the boys leaving achool gave work as the cause of withdrawal, it is really no excuse at all. To say that a boy quits to work simply means that he want to work when he quit and does not explain why he preferred work to school. An examination into the financial standing of the families of these boys shows that a great many did niot need the boy to work at all. Work, and indifference, ${ }^{\text {failure }}$ are so intimately comnected that it is almost impossible to separate them and none of them is an answer to the question, why do pupils leave school. What.we wish to know is, why are they indifferent, why did they fail, and why did they prefer to work. Dislike for authority and bad conduct might be classed with the three just mentioned, they are results and not causes. These five that can not be accepted as causes, comprise $72 \%$ of the boys and $52 \%$ of the girls. Certainly the teacher and the course of study are reaponsible for some of these.

Those who prefer hunting and fishing and such activities as can not be called work were dafssed under the head of "Desire for Activity" . Truancy might have been classed under the same head, but truancy is really 

not a cause. Mr. Brobks says: "Truancy should be treated as a symptom, which may arise from several causes, and its appearance should be the signal for an immediate and searching inquiry after the real cause. This may be in the achool, and not in the boy."

Cigarette smoking and the reading of light literature were the bad habits complained of. It is wèll known that students who smoke cigarette can not do good work. With all the good literature at our command, we ought $\not \phi t$ to be able to remedy the habit of reading bad Ziterature, but the cigarette habit is much harder to deal with. The peraonality of a manly man who does not smoke will do more than any thing else.

Mr. Brobks' ideas on this subject have been given at some length because of the thoroughness of his investigation, but now let us consider a little perabnal investigation. In some respects a small school where there is only one teacher to the grade furnishes a better subject for study than a large one. In a large system, where many teachere teach the same grade of work, a poor teacher here and there does not have much effect on the total results, and that little effect is hard to trace. In a small school, however, if there is any connection between the work of the teacher and the withdrawals from school, it should be very easily detected.

In keeping the record of withdrawals at California, Mo.,much the same classification as that used

Ed. Rev.,Vol. 26, p. 365 

by Mr. Brooks was followed, but for this discussion they are grouped somewhat differently. They are arranged in three tables (p.35). The first shows the percent of loss by grades for six years; the second showa the percent of loss by removal, sickness, work or other necessary causes; the third shows the percent of loss from indifference, failure, punishment, or other unnecessary causes. It might be said here that no bne is classified as quitting to work unless his work was necessary to the support of the family. If there is any doubt about the matter, they are given the benefit of the doubt. This is perhaps as good a division as one can make and yet it is very imperfect, for it sometimes happens that a family which has moved to town to educate the children moves away again when the children do little gcod in school. For the sake of brevity those in the third table, who quit for unnecessary causes, will be spoken of as the indifferent.

The first table agrees in the main with Mr. Woodward's report for st.Louis, as may be seen from the totals: 1st grade, 13.2\%; 2d grade, 14.1\%; 3d grade,20\%; 4 th grade, 22.4\%; fifth grade, 23.8\%; 6th grade, $22.5 \%$; 7 th grade, $16.2 \%$; 8 th grade, $15.5 \%$. Now when we turn to the second table, wherecthe indifferent have been eliminated, we see no nuch agreement. These averages run as follows: lst grade, 10.7\%; $2 \mathrm{~d}$ grade, 9.1\%; 3d grade; $10.1 \% ; 4$ th $\operatorname{grade}, 8.3 \% ; 5$ th $\operatorname{grad} \theta, 11.1 \%$; 6 th grade, $5.9 \%$; 7 th grade, $6.8 \%$; 8 th $\operatorname{grad} \theta, 7.2 \%$. 

Table XV--Showing percent of withdrawals by grades for six years for Califomia, Mo. (First)

\begin{tabular}{|c|c|c|c|c|c|c|c|c|}
\hline Yr. II & $\begin{array}{l}\mathrm{Gr} \cdot 1 \\
13 .\end{array}$ & $\begin{array}{l}\mathrm{Gr} .2 \\
13 .\end{array}$ & $\begin{array}{l}\mathrm{Gr} .3 \\
18 .\end{array}$ & $\begin{array}{l}G r .4 \\
20.6\end{array}$ & $\begin{array}{l}\text { Gr. } \\
30\end{array}$ & $\begin{array}{l}\mathrm{Gr} \cdot 6 \\
30 .\end{array}$ & $\begin{array}{l}\text { Gr.? } \\
18 .\end{array}$ & $\frac{\mathrm{Gr} .8}{17.2}$ \\
\hline$" 2$ & 16.3 & 15.8 & 20. & 30. & 20.6 & 24.5 & 12. & 27.6 \\
\hline & 8. & 15.2 & 30. & 18. & 5. & 20. & 9. & 20.7 \\
\hline & 18.4 & 14. & 22. & 23. & 30. & 18.4 & 10. & 10.7 \\
\hline & 10.4 & $12.7^{\prime}$ & 20. & 33.3 & 25. & 25. & 25 & 0. \\
\hline & & 74 & 20. & 13.6 & 20.6 & 14. & 23.5 & 17.2 \\
\hline & 13.2 & 14.1 & 21.6 & 22.4 & 23.8 & 22.5 & 16.2 & 15.5 \\
\hline
\end{tabular}

Table XVI--Showing percent of withdrawals fot causes other than indifference and failure. (Second)

\begin{tabular}{|c|c|c|c|c|c|c|c|c|}
\hline$\perp$ & $\begin{array}{r}\text { Gr.I } \\
8.6\end{array}$ & & & & & & 7. & \\
\hline 12 & 16.3 & 11.3 & 10. & 9. & 8.6 & 5. & 4. & 17.3 \\
\hline & & & 5. & 3. & & 8. & & \\
\hline & 14 & 8.7 & 10. & 6.4 & 10 & 5.4 & 3.3 & \\
\hline & & 9. & 12. & 13.3 & 17.5 & 5.6 & & \\
\hline & & & 39 & & & 5.6 & 16.5 & 6.9 \\
\hline & & 9.1 & 10.1 & 3.3 & 11.1 & 5.9 & .8 & \\
\hline
\end{tabular}

Table XVII--Showing percent of withdrawals fox: indifference or failure. (Third)

\begin{tabular}{|r|c|c|c|c|c|c|c|c|}
\hline Yr.1 & 4.4 & 5. & 10. & 13. & 16. & 24. & 11. & 9. \\
\hline$n 2$ & 0. & 4.5 & 10. & 21. & 12. & 19.5 & 8. & 9.8 \\
\hline$n 3$ & 2. & 6.7 & $25 . *$ & 15. & $2.5 * 12$. & 6. & 13.7 \\
\hline$n 4$ & 4.3 & 6.3 & 12. & 16.6 & 20. & 13. & 6.7 & 7.1 \\
\hline$n 5$ & 1.1 & 3.7 & 8. & 20. & $7.5 * 19.4$ & 18. & 0. \\
\hline "6 & 2.4 & 5. & 4. & 13.3 & 16.6 & 8.4 & 7. & 10.3 \\
\hline Av. & 2.4 & 5.2 & 11.5 & 14.8 & 10.8 & 16. & 9.4 & 8.3 \\
\hline
\end{tabular}



It is evident then, since the first tabie ahows the greatest loss in the fourth, fifth, and sixth grades and the second, where the indifferent have been eliminated, does not show the greatest loss in those grades, that the great loss in the grades under discussion is due to those that have been designated as the indifferent. The third table confirms this conclusion by the following averages: Ist grade, $2.4 \%$;2d grade, $5.2 \%$; $3 \mathrm{~d}$ grades, $11.5 \%$; 4 th grade, 14.8\%; 5th grade, $10.8 \%$; 6 th grades, $16 \%$; 7 th grade, $9.4 \% ; 8$ th grade, $8.3 \%$.

The question now arises, why should there be more indifference in those grades than in others. The trouble must be with the pupil, the teacher, the school system, of the curriculum, as these are the factors that make the school.

Let us first consider the pupil. It was Holmes who said, "If you wish to educate a man, you must begin four hundred years before he is born". We can not expect to produce an educated man from uneducated ancestors in one generation any more than we can expect to produce a race horse from common stock in one generation. Our pupils come from all kinds of homes, representing all degrees of culture, and it does not seem unreasonable to suppose that many of them will reach the limit of their capacities for development and necessarily drop out. If we grant the supposition for the sake of the argument, 

is it reasonable to suppose that a larger number would reach the limit of their capacities in the fourth, fifth, and sixth grades than in the others? There seems to be no reason why such should be the case, unless these grades present unusual difficulties, and in that case the blame would rest after all on the curriculum. We can safely say, that while many of the withdrawals may be accounted for by the inherent weakness of the pupils, the marked increase in those grades ( as shown by the rise from $5.2 \%$ in the $2 d$ grade to the $14.8 \%$ in the fourth) can not be accounted for in any such way. Let us next consider the teacher. If we are to hold the teacher in any way responsible for the greater percent of loss in the fourth, fifth, and sixth grades, we must show why the teachers of those grades should be less competent than those of other grades. In the schools of California; Mo., and the same is true of a good many other schools, the Board has gone on the theory that we need expert teachers fot the first and second grades and also for the seventh and eighth but that moat any one will do for the intermediate grades, hence they get poorer teachers generally: generally, becaupe there would naturally be exceptions, and there are exceptions. Now let us consider these exceptions in connection with the copditions found in the tables and see if they are in any way related. If they are it will protie a vital relation between the teacher and the withdrawals for indifference. 

Looking at table XVII we find the first marked exception in grade five for the third year. Here the loss is $2.5 \%$, the lowest of any of the intermediate grades for any year. What may be aid of the teacher for that for that year? She was a woman of mature mind, considerable experience, and excellent training, who gave up a better position to come to our school so she could be at home. She put life into her geography work by taking her class on field excursions and taking them to visit the various factories of the town; having them make relief maps of the countries they were studying, letting the pupils do all of the work, preparing the pulp from the scratch paper used in the room, etc. She also made good use of geographical readers, taking her pupils on imaginary journeys, and using many other devices to break the dull monotony of text-book work and make the subjedt a live one for the pupil. The grography work and nature study were made the foundation for language. The pupils were glad to write because they had something to tell. She carried the work still farther and used it to teach drawing and painting. With all she had a soul full of sympathy for her pupils. Her formar Superintendent described her as a born teacher. This was evident. She received $\$ 30$ more per month elsewhere the next year and left us. The following year we find a loss of $20 \%$, an increased Toss of $17.5 \%$; or if we follow the same 

pupils into the sixth grade, we find a loss of $13 \%$, an increase of $10.5 \%$.

The next exception worthy of note is of an opposite character and comes in the third year of the third grade; the $108 \mathrm{~s}$ of $25 \%$ is more than double that of any other year for the third grade. Here we have an inex-

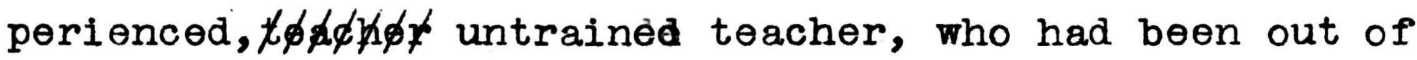
school and out of touch.with school affairs for several years. She had a good ming and was conscientious and energetic, but knew no more about teaching than simply assigning a lesson and hearing the pupils recite. Her first year was practically a failure, but energy has won, by hard work and earnestness she has become a good teacher and her improvement ig relected in the record. Notice the record for the third grade; $12 \%, 8 \%$, and $4 \%$. These two cases are sufficient to at least suggest a relation between the teacher and withdrawals for indifderence, but attention should be airected to one more exception because it is the work of an inexperienced but well prepared, enthusiastict $\phi \not d$ teacher. Reference is to the $7.5 \%$ in the fifth year of the fifth grade ( the year previous the loss was 20\%). This teacher came to us from the University of Texas prepared to do High School work, but on account of being inexperienced she failed to get a High School position and accepted a place in the grades. The second year she was promoted to the sixth grade where she reduced the $108 \mathrm{~s}$ for indif- 

ference from $19.4 \%$ to $8.4 \%$, the following year she was promoted to the High School. These three exceptions are stromg proof that the teacher is a very important factor in this problem. Let us have more well equipped, well trained, enthusiastic teachers and conditions will be much improved.

Let us now consider briefly what has been designated as the school system, meaning by that what is sometimes called the school machinery, of the rules and regulations of the school, the way it is graded, the way promotions are made, etc. In small schools where there is only one teacher to the grade and promotions are made but once a year, if a pupil does not make the required grade for promotion, he is compeled to go over the entire year's work again. No matter how vell he may know the first part of the work, he has to drag over it again, and it is no wonder he gets indifferent, fails again, and drops out. A lock step system of grading is one of the worst thinga a school can have. In the cities where the grades are only a few weeks apart it is much better but there is an evil there to be guarded against. Where the grades are close together and it does not mean the loss of a whole year to hold a pupil back, there is a strong tendency to hold him back and continue holding him back until he is far behind where he ought to be. Bvery school should have an ungraded room. The most significant fact in this investigation 

is that pupils who withdraw from school are uniformly above the normal age. It matters not whether we loom at St. Louis, Boston, Chicago, Boonville, or California, the same condition confronts us. Many who have been in school long enough to have finished the course drop out with it only half completed. Certainly this can not be entirely due to the dullness of the pupil. It can not be denied that many pupils are dull but we teachers frequently use te dullness of the pupil as a haven of refuge from our own faults.

Assuming that the pupil is largely to blame and that the teachers are partly at fault, still there must be something the matter with what we are offering in the curriculum. If it were what it should be it would appeal more strongly than it does to the pupil. A careful investigation of the curriculum will probably throw some light on the wquestion. However, before going into a general discussion of the course of study, a brief look at some peculiarities of the course at Calicornia, Mo. may prove suggestive.

In the tables for California it was seen that there was a great loss in the fourth, fifth, and sixth grades but that the loss in the fifth was not so great as in the other two. A comparison of the $29.4 \%$ average for the fourth grade in the first table (page 35) with the $14.8 \%$ average for the fourth grade in the third table shows that $62 \%$ of those who drop out in the fourth grade do so from what we have called indifference; a comparison of the averages fot the sixth grade in the ame way 

shows that $71 \%$ of the loss in that grade is due to indifderence, but in the fifth grade only $45 \%$ is due to that caues and in most other grades even less. A glance at the course of study reveals the fact that in the fourth grade a text-book is introduced in arithmetic, geography, and language; and in the sixth grade advanced texts are introduced in arithmetic and geography. This suggests that a sudden introduction of text-books when the pupil has not been sufficiently trained in the getting of thought from the printed page is likely to produce failure and a repetition of work is likely to produce indifference. It may be said, however, that this is the fault of the teacher for a skilful teacher will introduce the use of the book slowly and will give interest to the work when repeated in an advenced form. This is probably true but still there seems to be some conpection between the course of study and indifference.

In this study we have confined the investigation largely to those we have classed ad indifferent because they formed the greater part of the loss and because they are the ones the school is most likely to be responsible for. We have found that the pupil is much to blame, that part of the fault is with the teacher, and that the school system may be partly responible. In addition, we have found in the statistics for California some facts which point to the curriculum as a possible cause of withdrawals. In view of these considerations, it might be well to examine the course of study. 

Some Principles Underlying the Course of Study

If we wish to find out to what extent the course of study is to blame fot the witherawal of pupils, we must first determine what is the purpose of education. We must know what we wish to do before we can decide how to do it. The end will determine the means.

Most all educators agree that the highest aim of education is complete living but here the agreement ends. When we ask what is meant by complete living, we get a variety of answers. Perhaps the different ideas of complete living can best be given by telling how the different schools of education would reach this goal. Dr. W. T. Harris would prepare for complete living by a symmetrical development of all the powere. This is sometimes called the culture theory. Fe aivides human knowledge, religion being excepted, into five co-ordinate groups: the mathematical and physical; the biological, including plants and animals; literature and art; grammar, leading to logic and psychology; and history. Each of these groups is supposed to deal with a distinct phase of nature and to have a special method of its own. Fot example, biology deals with nature from the stand point of life while mathematids deals with it entirely from the stand point of quantity. In the former we have life or growth as the controling idea of our investigations, while in the latter, quantity or number is the controling thought. Assuming 

these five co-ordinate groups, each dealing with a distinct phase of nature in a method peculiarly its own, it is argued that each of these groups should be represented in every part of the curriculum. Thus and thus only can the symmetrical development of all the powers be accomplished. In forming a course of study from the subjects divided into these groups, it is best to look more at the man and less at the child. The subject matter must be selected entirely with a view to the fully developed man and we must study the child only to discover how best to adapt this subject matter to the present capacity of the pupil. Child study should have nothing to do with the selection of material but only with the mathod of presentation. The curriculum suggested by Dr. Harris, based on these principles, gives the most prominence to literature and history as these have the greatest influence in the formation of character and the making of citizens.

If we accept the assumption of the five co-ordinate groups and admit that each should be represented in every part of the course, would it be wise to select the. subject matter with a view only to the development of the ideal man? Would a course formulated on that plan be likely to appeal to the masses of either the parents or the pupils? Only so far as their ideals conform to the ideal of the supervising officer who outlined the curriculum. Too many shool courses have been made to suit the supervisor and not enough to meet the demands of the pupils. 

Spencer also takes complete living as the highest aim, of education, but as knowledge is valuable only as a guide to action, he makes human activities the key to the curriculum. The activities of life are divided into five classes: Those which minister to selfpreservation; those which indirectly minister to self preservation, that is to the necessities of life; those which have for their end the rearing and disciplining of offspring; those which are involved in the maintenance of proper social and political relations; and thosed activities which make up the leisure part of life, devoted to the gratification of the tastes and feelings. These activitick are named in the order of their importance and studies are valuable as they prepare for these activities. Self preservation being the first law of nature, care of the body is of mot importance. The first requisite $\not f$ to success in life is a sound body, hence nothing must be allowed to injure the health. There must be no hampering of phyoical activities and no breaches of physical laws. For direct preservation of self, the knowledge of science is of most value; for indirect preservation, or gaining a livelihood, the knowledge $\phi$ of science also of most worth; for the due discharge of the duties of a parent, science is the proper guide; for a thorough understanding of national affairs and the duties of citizenship, we must look to science; for the most perfect production and fullest enjoyment of art of all kinds, 

the best preparation is science; and lastly, for the purposes of discipline,intellectual, moral and religiois, science gives the best training. "If man would find tongues in trees, books in ranning brooks, sermons in stones, and good in every thing, he must list to nature's teachings." Thus with spencer and thoes of his school, science would be the chief element of the curriculum. However, he would not exclude any of the groups of human knowledge but he would make them secondary to science. The test of every plan of culture should be its power to produce a pleasurable excitement in the pupil.

Accordin to Spencer, then, in making a course of study the first consideration should be the health of the pupil; the next should be dtility, in the narrow sense of the word; third, those things which make fort a better home life; fourth, those things which make for good citizenship; and last, what is usually meant by culture in its narrow meaning. Certainly every subject could find a place in a curriculum based upon such principles.

Another school of educators, among whom are Dewey, McMurry, and Hanus, make social efficiency the aim of education. This might be called the Biological view-point. It recognizes"the struggle for existence" and "the survival of the fittest" as the means of human progress, and asserts that whatever most aids man to adapt himself to the present conditions of society is $6 \mathrm{f}$ most value. The aims of the school and the aims of society 

must be the same, and as the aims of society change so must the aims of the school. Hanus aays: "The education demanded by a democratid society to-day is an education that prepares a youhh to overcome the inevitable difficulties that stand in the way of his material and apiritull advancenent; an education that, from the beginning, promotes his normal physical development throush the most salutary environment and appropriate physical training; that opens the mind and lets the world in through every natural power of observation and assimulation; that cultivates hand power as well as head power; that inculcates the appreciation of beauty in nature and in art, and insists on the performance of duty to self and to others; an education that in youth and early manhood, while continuing the work already done, enables the youth to discoter his own powers and limitations, and that impels him through oft repeated intellectual conquests or other forms of productive effort to look forward to a life of habitual achievement with the head or with the hands, or both; that enables him to analyze for himself the iftellectual, economic, ans political problems of his time, and that gives^insight, the interest, and the power to deal with them as successfully as possible for his own advancement and for social service; and, finally, that causes him to realize that the only way to win and to retain the prizes of life, namely, wealth, culture, leisure, honor, in an ever increasing usefulness, and thus makes him feel that a 

Iffe without growth and without service is not worth living."

This school of educators, in planning a course of study, look more to the child and less to the man; they claim that what ever $\not \not \phi$ best mee+s the present needs of the child gives the best prepatation for the future. Instead of giving the chid something to do that he can not see the use of and telling him tat it is fitting him for future life, they propose to give him something that will satisfy a present need of the child.

While these are some of the theories of modern educators, very few courses of study are actually based upon them. Most of our curriculya are composed of two parts; one, s heritage of the past; the other, a lot of miscellaneous subjects that have been grafted on to the old stock in response to a persistent demand for a modification of the traditional course to meet the demands of modern society.

Dr. Dewey gives the best analysis of the situation: "For twenty fue years the educational $f \neq$ reformer has been calling for an enrichment of the course of study and the conservative has just as strenuously opposed it. In the field of argument the reformer has asily been victorious from the very beginning of the struggle; in practice,however, the conservative has had his own way until recently. Vanquished in argument, the conservative often adopted the Ed. Rev. Vol. 22, pp. 26-49. 

phrases of the reformer in toachers meetings but in actual practice he went on about as he had done before. Each side was satisfied thinking the victory was with them.

After a while the reformer awakened to the fact that few of his theories were being tested by actual practice of the school room. The conservative, in the person of the teacher and the patrons, had effectually blocked his work; his reforms were looked upon as fads. Then began the struggle to introduce the "enriching" studies into. the course of study. Gradually here and there the newer studies forced their way into the curricula of the schools but they never really became parts of the course; they remained as something external, forced in but not assimulated. The traditional three $R^{\prime} s$ still formed the main part of the curriculum and the"enriching" studies were frequently dropped when it was discovered that children did not spell as well as thsy did before or that they did not gain as great proficiency in number work as they did before the newer studies were introduced.

$$
\text { If putting the new studies into the printed }
$$
curriculum were suffieient, the victory would have rested with the reformer long ago; but unfortunately this was not the case. The making of them into an integral part of the course of study devolved on the teacher and she, as a rule, was unequipped for the work and did not understand the real purpose of these studies in the course and their relations to the other studies. The 

result was an over crowded surriculum, an over worked teacher, poor work in general, dissatisfied pupils, and frequently the withdrawal of pupils from school.

The conservative declared the whole thing a failure and wished to throw the new studies over-board, but the reformer laid all the trouble on the inefficient teacher. The next stepiwas the introduction of the special teacher. While the specialist certainly improved the instruction in her subject, she usually had no better idea of the proper relation of her subject to the remainder of the course than did the unprepared teacher, so that the conjested condition was not relieved.

Most of our courses of study are over croulded because the new subjects have been added but have not been ass in the curriculum have not been definitely determined; they are supervised by specialists, each of whom considers his subject as ths all important one, and taught by teachers who still consider the three $R^{\prime} \mathbf{s}$ as of supreme importance.

Another condition which interferes with the ueefulness of the new studies is the school machinery. The old school machinery with crowded school rooms is not adapted to any thing but routine and drill and they are directly opposed to the spirit of the new studies. In this inquiry the facts that have been set forth in regard to the course of study are important only as they affect the witharawal of pupils from school, but is 

it not a natural deduction that such a state of unrest, uncertainty, and lack of proper adjustment in the course of study would produce unrest, lack of interest, and frequent withdraval wmong the pupils? In the first part be this paper it was found that Boston had a better record than st.Louis in retaining her pupils. Mr. Woodward attributes this to the fact that Boston introduced manual training and domestic science into the course of study several years sooner than St.Louis. Whether that is the correct explanation or not, the introduction of thoee subjects in st.Louis has been followed by an imp*Rovement in the length of school attendance; so there is strong grounds for believing that there is a relation $\not 6$ between the two facts. If the introduction of the "enriching" studies prolongs school attendance, might we not expect continued improbement as these subjects become better assimulated and find their proper place in the curriculum?

The remedy usually suggested for the conjested condition of the curriculum in omissions. Let us look for a moment at the principles involved in some of the suggested omissions. We have known for a long time that we were teaching many things that were of no practical value but they were retained because they were thought to be valuable as mental discipline. Modemal Psychology teaches that all discipline is largely special and only to a slight degree general. Hence it is a waste of time to learn any thing of no practical value 

for the sake of the little general training derived from it. Utility (not in the narrower sense) should be one of the prominent principles in the selection of the subject matter of the curriculum.

F. M. McMurry has given us some very definite principles to guide in making omissions: First, whatever can not be shown to have a plain relation to some real need of life, aesthetic, ethical, or utilitarian, shoudd be omitted. Srcond, whatever is not reasonably within the child's comprehension should be dropped. Third, whatever is not likely to appeal to the child's interests should be omitted uhless it is demanded by the first test. Fourth, whatever topic ot details are so isolated or irrelevant that they are not a part of any series of ideas and therefore fail to be necessary forth the appreciation of any large point should be dropped. However, he woudd not have this last test apply to the three $R^{\prime}$. These principles taken negatively are about the same as we have already seen suggested by one school as tests in constructing a course of study. It has already been shown, however, that few curricula are based on these principles. This is perhaps the reason why they fail to meet the needs of the pupils and thus lose hold on them.

Ed. Rev., Vol. 27, p. 478. 



\section{A Comparison of A Few Courses of Study}

As St.Louis has received considerable attention in this inquiry, it would probably be of interest to take a brief look at her course of study. This may be taken as typical of the curricula of the schools of the larger cities, for, regardless of differences in details, the principtes underlying them are very much the same. Cn pages 54, 55, and 56 the outline of the course for this yeat, the notes on the outline, and the time alloted to the different subjects are given. It will be noticed that the outline does not include nature study, drawing, physical culture, manual training, domestic science, and lessons on comduct, but they each have special courses printed in pamphlet form. This would seem to indicate that those subjects receive special attention, but it also shows their external position in the curriculum; it show they are still looked upon as additions. Again, they each have a separate corps of supervisors, which is further proof of their eternality. If the standing of these subjects were as well established as is that of the older subjects, this special effort would be entirely unnecessary; the rank and file of the teacher would be required to be as well prepared in these subjects as in the older ones. One of the most efficient teachers in the city was heard to say recently that it was a pity to spend so much time on frills when it could be used so much better on subjects that amount to something. That remark represents the atitude of a great many of the teachsrs toward the"enriching" studies as they are taught. 

OUTLINE OF THE COURSE OF STUDY.

Where the page of a text-book is given, it means that the work of the quarter includes that page.

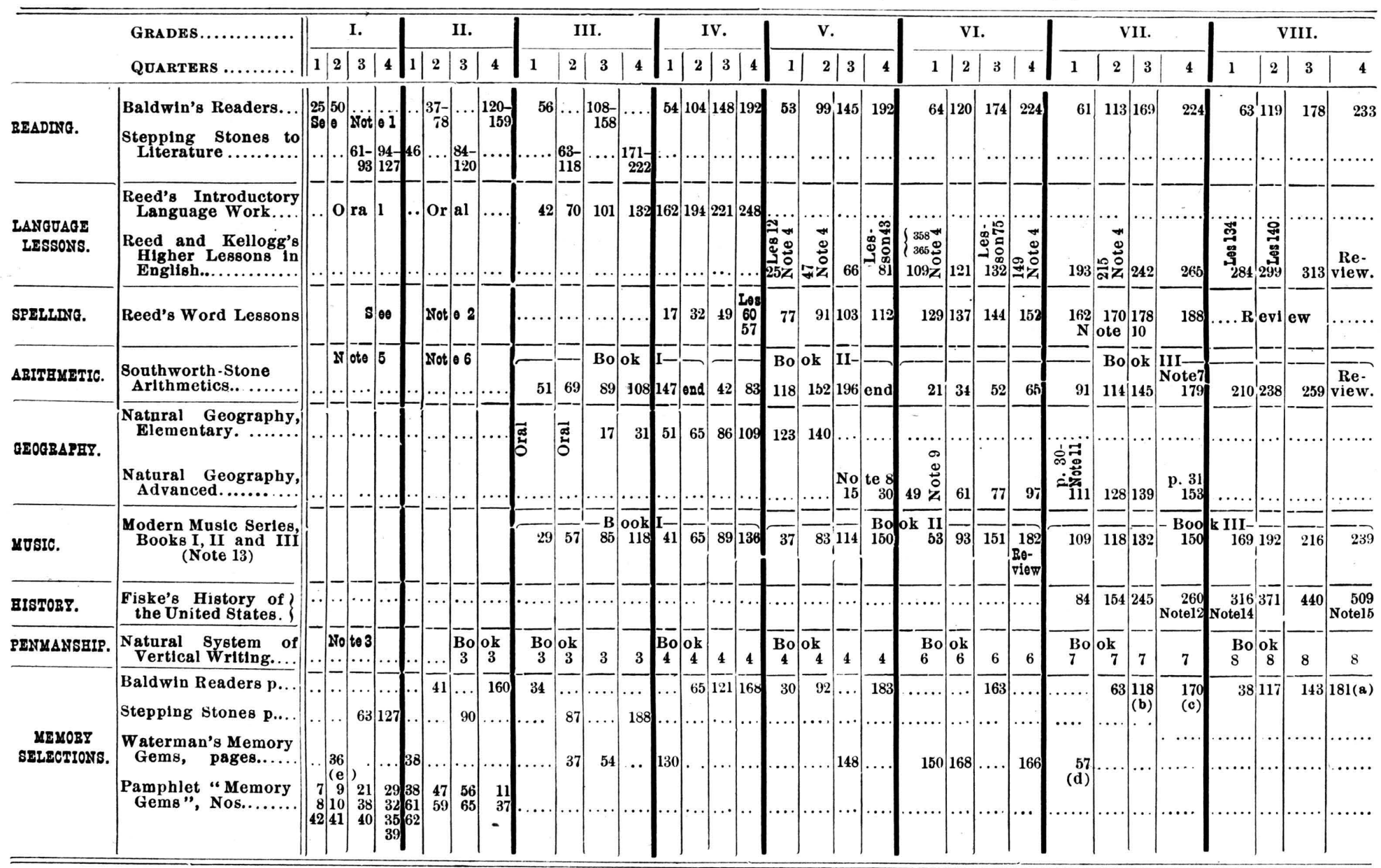



Note 1, Primary Reading. - The first ave weeks no print. Script reading from blackboard, exclusively. For first lessons, action

words are selected (sit, run, jump, etc.). Second half quarter, script and print.
The assignment of Readers, as given above, is obligatory; Baldwin's the first half year for every class; “ stepping The assignment of Readers, as given above, ls obligatory; Baldwin's the first half year for every class; " Stepping
stones" the second. While the one set is used as the regular text-book, the other set is used simultaneously for supplementary reading: First half year, "Stepping Stones" p. 60 (not beyond); second half year, 51-128.

Notr 2, Primary spelling by sound begins sixth week, first quarter; by letter first week, second quarter.

NOTE 3, Writing. - No pencll or pen to be used durlng flrst quarter. "Shlpping" Crayons take their place. Use large sheets of manila paper. Heavy wood-covered crayons (“,Nerograph”) and manlla paper used during remainder of first year.

Note 4, Some parts in the Higher Lessons are to be omitted as follows: Introductory suggestions and foot notes; exerclses like the one at the bottom of p. 35; distinction between different classes of a dverbial clauses, pgs. 146 to 169 ; subclassification under "conjunctions."

Note 5, Arithmetic 1st Grade, 1st and 2nd quarters, numbers from 1-12; 3rd quarter, to 20; 4th quarter, to 100 .

Notr 6, Arithmellc, 2nd Grade, 2's, 3's, 4's and 5's.

Notr 7, Arithmetic 7th and 8th Grade; omlt the following: pgs. 172-177 (Partial Payments); pgs. 182 and 183 (Compound Interest); pgs. 239-244 (Metric System).

Note 8, Advanced Geography; omit p. 19, Oxbow Loops; p. 21, Spits and Sandy Hooks; p. 28, second column, Tundras, and p. 29, first column, Deserts.

Note 9, Advanced Geography. - Only the most important citles to be studied, according to the prescribed list.

Note 10, The aim of this part of the Spelling Book is to teach discrimination in the use of diffeult words of kindred meanings and to lead the puplls to appreciate their peculiar application. It may not be possible to require children of this age to Invent original sentences in which these words are used, but they may be led to explain their meaning in sentences which the teacher presents.

Note 11, South America.

Notr 12, Constitution, pages 511 to 524. - Amendments 11 and 12

Note 13, Certaln pages are to be omitted; see pamphlet, Music Course of Study.

NOTE 14, Amendments 1 to 10.

NOTE 15, Amendments 13,14 and 15 .

Memory Gems: (a) - From 181 L. 19 to p. 182 L. 25. (b) - 118 L. 5 to 119 L. 2. (c) - 9 stanzas. (d) Dedication Address. (e) - Bed in Summer.

The Course of Study in Nature Study, Drawing, Music, Physlcal Culture, Manual Training, Domestic Sclence, and Lessons on Conduct, are printed in pamphlet form. 

GENERAL PROGRAM FOR THE DISTRICT SCHOOLS.

Number of Lessons per Week in the Several Studies in Each Gradk.

\begin{tabular}{|c|c|c|c|c|c|c|c|c|}
\hline . & $\begin{array}{l}\text { 18t Year } \\
\text { or Grade. }\end{array}$ & $\begin{array}{c}\text { 2d Year } \\
\text { or Grade. }\end{array}$ & $\begin{array}{l}\text { 3d Year } \\
\text { or Grade. }\end{array}$ & $\begin{array}{l}\text { 4th Year } \\
\text { or Grade. }\end{array}$ & $\begin{array}{l}\text { 5th Year } \\
\text { or Grade. }\end{array}$ & $\begin{array}{l}\text { 6th Year } \\
\text { or Grade. }\end{array}$ & $\begin{array}{l}\text { 7th Year } \\
\text { or Grade. }\end{array}$ & $\begin{array}{l}\text { 8th Year } \\
\text { or Grade. }\end{array}$ \\
\hline $\begin{array}{l}\text { Reading } \ldots \ldots \ldots \ldots \ldots \ldots \\
\text { Spelling } \ldots \ldots \ldots \ldots \ldots \ldots \ldots \ldots \ldots \ldots \ldots \ldots \\
\end{array}$ & $20\}$ & $\frac{10}{10(15 \mathrm{~m})}$ & $\frac{5}{5(15 \mathrm{~m})}$ & $\begin{array}{c}5 \\
5(15 \mathrm{~m}) \\
\end{array}$ & $\frac{4}{4(15 \mathrm{~m})}$ & $\frac{4}{4(15 \mathrm{~m})}$ & $\frac{3}{2(15 \mathrm{~m})}$ & $\frac{3}{2(15 \mathrm{~m})}$ \\
\hline Writing (Note 1) $\ldots \ldots, \ldots \ldots \ldots \ldots \ldots \ldots \ldots$ & 5 & 5 & 5 & 4 & 4 & 4 & 2 & 2 \\
\hline Arithmetic $\ldots \ldots \ldots \ldots \ldots \ldots \ldots \ldots \ldots \ldots \ldots \ldots \ldots \ldots$ & 5 & 5 & 6 & 5 & 5 & 5 & 5 & 5 \\
\hline 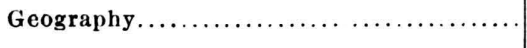 & & & 4 & 4 & 4 & 4 & 3 & \\
\hline Language Lessons and Grammar............ & ( 2 (Note & 2 & 3 & 2 & 2 & 2 & 3 & 4 \\
\hline 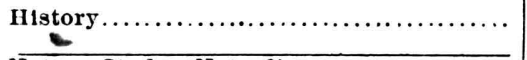 & & & & & & & 3 & 5 \\
\hline Nature-Study (Note 2$) \ldots \ldots \ldots \ldots \ldots \ldots$ & 1 & 1 & 1 & 1 & 1 & 1 & 1 & 1 \\
\hline 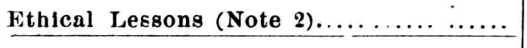 & 1 & 1 & 1 & 1 & 1 & 1 & 1 & 1 \\
\hline Drawing $\ldots \ldots \ldots \ldots \ldots \ldots \ldots \ldots \ldots \ldots \ldots \ldots \ldots \ldots \ldots \ldots \ldots$ & $5(20 \mathrm{~m})$ & $5(20 \mathrm{~m})$ & 4 & 3 & 3 & 3 & 3 & 3 \\
\hline 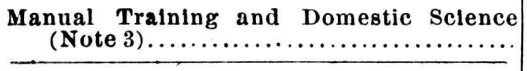 & & & & & & & 1 & 1 \\
\hline Music $\ldots \ldots \ldots \ldots \ldots, \ldots \ldots$ & $(15 \mathrm{~m})$ & 1 & 1 & 1 & 1 & 1 & 1 & 1 \\
\hline Callsthenics (Note 4)......... & $(10 \mathrm{~m})$ & $(10 \mathrm{~m})$ & $(10 \mathrm{~m})$ & $(10 \mathrm{~m})$ & $(10 \mathrm{~m})$ & $(10 \mathrm{~m})$ & $(10 \mathrm{~m})$ & $(10 \mathrm{~m})$ \\
\hline $\begin{array}{r}\text { Maximum Length of Lessons in Minutes } \\
\text { Except for Spelling................................. }\end{array}$ & \} & 25 & 25 & 30 & 30 & 30 & 30 & 30 \\
\hline
\end{tabular}
Note 1.- Exercises for the whole room. Singing at least ten minutes each day at opening or closing of session, besides the
regular weekly music lesson. The length of lessons for each grade applies to all recitations except drawing in the second grade and spelling in all grades.
NOTE 2. -Oral for the whole room, as indicated in the Course of Study.

NOTE 2. - Oral for the whole room, as indicated in the Course of Study.
NOTE 3. - This one lesson requires an hour and a half in the work room, and requires this time for each class of each room when the classes are not combined in this work. Make such comblnations in the dally program as will make room for this work; for

instance, combine the classes in reading and make it an exercise for the whole room, etc.
NoTe 4 . - Calisthenics, ten minutes each day. 

If there is any doubt as to what is the main part of this course of study, it disappears when we look at the program on page 56 showing the amount of time alloted to each subject. The three $R^{\prime} s$ are evidently the main body of the curriculum. For the first two years reading gets the most attention, but from then on arithmetic takes the lead with 6 recitations a week in the third year and 5 per week through out the remainder of the course. With drawing excepted, and one of the three $R^{\prime}$ s receives about as much time as all the Nenriching" studies combined. When this is the case, is it any wonder that the teachers consider the three $R^{\prime} s$ as the esentials and the other studies as "frills"? In some instances the table may not be exactly fair. Language, for example, is given only 2 or 3 reditations per week, but every lesson is supposed to be'a lesson in language. Making all due allowances, however, we must admit that the three $R^{\prime}$ s constitute the chief part of the program.

The notes on the course of study are of interest also. Notes 4,7, 8, 9, and 13 show that the plan of omissions is being tested. The condition as shown in this course of study seems to comform very nearly to those described by Dewey in The Educational Situation. The course is based on the traditional studies with the newer ones grafted on but not yet become an integral part of: it and an attempt is being made to relieve the confestion by judicious omissions. 

The reading course as bere outlined does not give any adequate idea of the work really done. This gives only $\not$ the work in the adopted texts and that is but a small part of what is realiy done. The St.Louis schools are well supplied with supplementary readers and the larger part of the work is done with these. In addition to the large supply of supplementary readers furnished to each school the Bublic Library has a great many sets of excellent books that are at the services of the schools. While it is outlined as reading for the full eight years, it is really literature. In 1

In language it would seem that an unusually large amount of time is alloted to formal grammar; geginning in the fifth grade it is continued thoughout the course, making four years in all. This, may have something to do with such a large withdrawal of pupils from the fifth grade. Pupils of that grade are hardly ready to take up the study of formal grammar and find no interest in it. In geography the study-recitaion is used and the lessons are illustrated with a stereopticon.

Taking this as a type of the usual puplic school course, let us consider some of the curricula offered by the experimental schools. It has been said before that few courses of study were really based upon the theories of modern educators. There are however a few exceptions to this rule. The speyer school, for instance, has broken loose from tradition and attempted to formulite a course strictly on modern pedagogical principles. This is an experimental school under the managment of the Columbia 

University Teachers College, a place where educational theories can be tried and tested.

F, M. McMurry has given a summsry of the controlling ideas in the school: =Health being the most important factor in social efficiency,. must also be paramount in the school. Whenever scholarship and health conflict, scholarship must always give way. The school must not only look after the health of the pupil but also that of the parent; the school owes a duty to the adults of the community as well to the children. Since usefulness in I.ife depends upon the ability to do something, the second controlling idea is that a good education combines learning with doing. According to the Bilological view-point the object of thought is to direct action, action is the all important thing of life. In most occupations of life thinking is the leseer part and doing, the greater ; then the same relation should exist in the school. It better fits the pupil for life, and at the ame time makes his thinking more accurate, for nothing is so good to correct erroneous ideas as to try to fit them to the facts. It also trains pupils for leadership and administrative duties. The thira aim of the school is the development ot permanent interests. Interest gives force, strength, and energy to accomplish ends. The man who has no permanent interests is a failure.

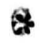
Teachers College Record, Vol. III, No. 5, p. 32 . 

From this statement of the controlling ideas of the schoolit it is evident that it is under the management of that school of educators which considers the highest aim of education as social efficiency. The controlling ideas of the school show the principles on which the curriculum is based. Mcliurry sums them up under two heade; the demands of society, and the nature of the child. As health is of most importance, physical cultare and the laws of health are given great emphasis. Aside from this, the greater part of the first two years is taken up with the observation and reproduction of surrounding occupations. The object of this is two fold, to bring the child into contact with social life, and to form a basis for the understanding of distant and imaginary events and objects. This leads back to the study of primitive life and history. Next in importance comes manual training. Arithmetic and writing are not given as separate subjects in the first two years but are entirely incidental to the other work of the school; in fact, they are taught throughout the entire course only as the pupia feels the need of them in the occupations of the school. Nothing better shows the difference in the ideals between this course of study and the one we have just looked at than the simple outlines. For this purposeth the outline of the speyer curriculum in given on pages 61 and 62. In the former every thing was given in figures by the numbers of the 

OUTLINE OF CURRICULUM

\begin{tabular}{|c|c|c|c|c|}
\hline Subjects & \multicolumn{2}{|c|}{ K I N DERGARTEN } & First Grade & SeCond Grade \\
\hline \multirow[b]{2}{*}{$\begin{array}{l}\text { SURROUNDING } \\
\text { OCCUPATIONS } \\
\text { AND } \\
\text { Primitive LIFE }\end{array}$} & \multirow{2}{*}{$\begin{array}{l}\text { FIRST YEAR } \\
\text { Morning Circle, Games, and } \\
\text { Stories are based partly on } \\
\text { SurroundingOccupations and } \\
\text { Primitive Life. }\end{array}$} & SECOND YEAR & \multirow[b]{2}{*}{$\begin{array}{l}\text { The Home; the Street; } \\
\text { Buildings; Vegetable and } \\
\text { Fruit Gardens; Grocery } \\
\text { Store; Ice Industry; Bakery; } \\
\text { Butcher Shop; Dairy Store. }\end{array}$} & \multirow[b]{2}{*}{$\begin{array}{l}\text { Vegetable and Fruit Gar- } \\
\text { den; Typical Farm; Village; } \\
\text { Eskimo Life; The Home; } \\
\text { Frame Building; Lumbering; } \\
\text { Brickmaking; Quarrying. }\end{array}$} \\
\hline & & $\begin{array}{l}\text { Morning Circle, Games, } \\
\text { and Stories are based partly } \\
\text { on Surrounding Occupations } \\
\text { and Primitive Life. }\end{array}$ & & \\
\hline Nature Study & $\begin{array}{l}\text { Talks based on Excursions } \\
\text { to Parks and Woods and on } \\
\text { material collected on these } \\
\text { Excursions. }\end{array}$ & $\begin{array}{l}\text { Excursions to Parks and } \\
\text { Woods: Observation and } \\
\text { Naming of Objects of } \mathrm{Na}- \\
\text { ture. }\end{array}$ & $\begin{array}{l}\text { (Following the order of sea- } \\
\text { sons) Observation and Nam- } \\
\text { ing of Characteristic Plants } \\
\text { and Animals; Study of Pro- } \\
\text { cesses of Growth and Meta- } \\
\text { morphosis; Home Pets; Gar- } \\
\text { den Products; Excursions. }\end{array}$ & $\begin{array}{l}\text { Return of Life in Spring; } \\
\text { Germination of Seeds; Care } \\
\text { of House Plants; Study of } \\
\text { Plants and Animals related } \\
\text { to Surrounding Occupations } \\
\text { and Primitive Life. }\end{array}$ \\
\hline HAND WORK & $\begin{array}{l}\text { Work with Ist, 2d, 3d and } \\
\text { 4th Gifts and with other } \\
\text { Material; Pricking; Sewing; } \\
\text { Weaving; Pasting; Cutting; } \\
\text { Clay Modelling; Sand-table } \\
\text { Work. }\end{array}$ & $\begin{array}{l}\text { Work with 5th and 6th } \\
\text { Gifts and with Sticks, Rings, } \\
\text { Tablets, and other material; } \\
\text { Coloring; Sewing; Weaving; } \\
\text { Folding; Clay Modelling; } \\
\text { Sand-table Work. }\end{array}$ & $\begin{array}{l}\text { Objects and Processes Stu- } \\
\text { died elsewhere are represent- } \\
\text { ed by use of Paper and Card- } \\
\text { board (cutting, folding, and } \\
\text { pasting) and of Clay, Raffia, } \\
\text { Cord, Crayons, and Paint. }\end{array}$ & $\begin{array}{l}\text { Wood Work; Sewing; } \\
\text { Weaving; Cooking; Mould- } \\
\text { ing; Drawing; Painting - } \\
\text { closely related to Occupa- } \\
\text { tions, Literature and Mathe- } \\
\text { matics. }\end{array}$ \\
\hline Mathematics & $\begin{array}{l}\text { Not differentiated from } \\
\text { Gift Work, Games, and } \\
\text { Hand Work. }\end{array}$ & $\begin{array}{l}\text { Not differentiated from } \\
\text { Gift Work, Games, and } \\
\text { Hand Work. }\end{array}$ & $\begin{array}{l}\text { Counting; Notation; and } \\
\text { Units of Measure required in } \\
\text { other subjects. }\end{array}$ & $\begin{array}{l}\text { Estimating and Measuring } \\
\text { required in various topics; } \\
\text { Counting; Arabic and Ro- } \\
\text { man Notations. }\end{array}$ \\
\hline $\begin{array}{l}\text { ENGLISH : } \\
\text { Literature } \\
\text { Reading } \\
\text { Written Work }\end{array}$ & $\begin{array}{c}\text { Nature Stories; } \\
\text { Fairy } \\
\text { Tales; Myths; Folk Stories. }\end{array}$ & $\begin{array}{l}\text { Myths; Folk Stories; Fairy } \\
\text { Tales; Bible Stories. }\end{array}$ & $\begin{array}{l}\text { Stories; Poems; Fables; } \\
\text { Words of Songs. } \\
\text { Beginning Reading. } \\
\text { Large, rapid Movements at } \\
\text { blackboard; Writing Names, } \\
\text { Words and Simple Sen- } \\
\text { tences; Easy Dictation; Use } \\
\text { of Capitals. }\end{array}$ & $\begin{array}{l}\text { Appropriate Stories, Poems, } \\
\text { and Fables. } \\
\text { Keading from Primary } \\
\text { Readers and other Books. } \\
\text { Large writing encouraged; } \\
\text { Copying, Dictation, and easy } \\
\text { Composition; some common } \\
\text { Symbols and Forms. }\end{array}$ \\
\hline Music & Morning Circle; Musical Ga & ames; "Occupation" Songs. & $\begin{array}{l}\text { Training in Rhythm, Beats, } \\
\text { Duration, and Pitch; Har- } \\
\text { monic Character of Tones; } \\
\text { Syllables; Simple Songs and } \\
\text { Singing Games. }\end{array}$ & $\begin{array}{l}\text { Work of First Year Con- } \\
\text { tinued; Notation of Illustra- } \\
\text { tive Songs. }\end{array}$ \\
\hline $\begin{array}{l}\text { Physical } \\
\text { Exercises }\end{array}$ & Games; March & 1es; and Plays. & $\begin{array}{l}\text { Rythmic Drills; Dancin } \\
\text { of Normal Activities and } P \\
\text { Movements; Individual Ex }\end{array}$ & $\begin{array}{l}\text { g; Games; Plays; Imitation } \\
\text { rimitive Occupations; Formal } \\
\text { ercises. }\end{array}$ \\
\hline
\end{tabular}





\begin{tabular}{|c|c|c|c|}
\hline Subjects & Third Grade & Fourth Grade & FifTH GRADE \\
\hline $\begin{array}{l}\text { Primitive } \\
\text { Life; } \\
\text { History }\end{array}$ & $\begin{array}{l}\text { Story of Ab.; Thompson Indians; } \\
\text { Alqonquin and Iroquois Indians; Cliff } \\
\text { Dwellers and Pueblo Indians; Robin- } \\
\text { son Crusoe. The Great Industries - } \\
\text { Agriculture, Food Getting, Making of } \\
\text { Dwellings and Clothing, Trade and } \\
\text { Transportation, Preservation of Knowl- } \\
\text { edge, Assthetic Arts. }\end{array}$ & $\begin{array}{l}\text { Homeric Greeks - agricultural and } \\
\text { pastoral life; Later Greeks, particularly } \\
\text { the Athenians; Hebrews; Romans } \\
\text { characteristic social customs; Middle } \\
\text { Ages - Chivalry and the Crusades; } \\
\text { Discovery and Exploration. }\end{array}$ & $\begin{array}{l}\text { Explorations; Colonization in Amer- } \\
\text { ica - the Dutch in New York, the Eng- } \\
\text { lish at Plymouth Colony and in Vir- } \\
\text { ginia as types, Spanish and French } \\
\text { Colonies; Colonial History to } 1776 .\end{array}$ \\
\hline GEOGRAPHy & ( & $\begin{array}{l}\text { Topography of the immediate En- } \\
\text { vironment; a typical Village; New } \\
\text { York Harbor; Commerce, Industries, } \\
\text { and Government of the City. }\end{array}$ & $\begin{array}{l}\text { The Earth as a Whole with brief } \\
\text { study of Continents and principal } \\
\text { Countries. Detailed study of North } \\
\text { America begun. }\end{array}$ \\
\hline Nature Study & $\begin{array}{l}\text { The Great Food and Industrial Plants } \\
\text { and Animals related to Primitive Life } \\
\text { or to the School Environment; Simple } \\
\text { Principles of Physics; proper Food, } \\
\text { Water, and Clothing. }\end{array}$ & $\begin{array}{l}\text { Plants and Animals prominent in the } \\
\text { Study of History and Primitive Life; } \\
\text { Study of Atmosphere; Experimental } \\
\text { work with Lime, Cement, and Asphalt. }\end{array}$ & $\begin{array}{l}\text { Type Studies of Plants and Animals } \\
\text { in different sections; Observation of } \\
\text { the Heavens; the Barometer; Simple } \\
\text { Principles of Heating and Ventilation. }\end{array}$ \\
\hline HAND WORK & $\begin{array}{l}\text { Modelling in Clay; Woodwork; Cook- } \\
\text { ing; Sewing; Drawing and Color Work } \\
\text { in relation to Primitive Life and } \\
\text { School Environment. }\end{array}$ & $\begin{array}{l}\text { Variety of objects made in connec- } \\
\text { tion with study of Primitive Life and } \\
\text { History - using appropriate material } \\
\text { and methods. }\end{array}$ & $\begin{array}{l}\text { Making of objects representative of } \\
\text { Colonial life; reproduction of processes } \\
\text { common in Colonial life; Laundering; } \\
\text { Repairing; Crocheting; Color Work } \\
\text { and Drawing; Domestic Science. }\end{array}$ \\
\hline Mathematics & $\begin{array}{l}\text { Fundamental Operations; Measuring; } \\
\text { Geometrical Forms; Simplest Common } \\
\text { and Decimal Fractions in ordinary use. }\end{array}$ & $\begin{array}{l}\text { Drill in Operations; Denominate } \\
\text { Tables; Operations with Fractions; } \\
\text { Business Forms; Oral Work. }\end{array}$ & $\begin{array}{l}\text { Compound Numbers; Reduction of } \\
\text { Fractions; Operations with Decimal } \\
\text { Fractions; Business Forms; Oral Com- } \\
\text { putation; Concrete Geometry, as re- } \\
\text { quired in other work. }\end{array}$ \\
\hline $\begin{array}{l}\text { ENGLISH: } \\
\text { Literature } \\
\text { Reading }\end{array}$ & $\begin{array}{l}\text { Stories and Poems dealing with In- } \\
\text { dian Life; Mythology; Fables; other } \\
\text { Selected Literature. } \\
\text { Large amount of Reading from nu- } \\
\text { merous readers and story books. }\end{array}$ & $\begin{array}{l}\text { Selected Literature to be read by the } \\
\text { Teacher or by the Class. }\end{array}$ & $\begin{array}{l}\text { Silent and Class Reading of com- } \\
\text { plete pieces of Literature of consider- } \\
\text { able length. }\end{array}$ \\
\hline Written Work & $\begin{array}{l}\text { Position and Movement in Writing; } \\
\text { Composition - grammatical structure } \\
\text { and rhetorical qualities. Material for } \\
\text { Composition taken from other school } \\
\text { subjects. }\end{array}$ & $\begin{array}{l}\text { Grammatical Usage and Qualities of } \\
\text { Style studied in connection with letter- } \\
\text { writing and composition work. }\end{array}$ & $\begin{array}{l}\text { Frequent short Compositions - out- } \\
\text { lining, paragraphing, and grammatical } \\
\text { analysis. }\end{array}$ \\
\hline Music & $\begin{array}{l}\text { Staff Representation; Songs; Indi- } \\
\text { vidual practice in Singing and Writing. }\end{array}$ & $\begin{array}{l}\text { Sight Singing - individual and class } \\
\text { practice. }\end{array}$ & $\begin{array}{l}\text { Sight Singing - drill in quickness } \\
\text { and accuracy; Individual and Choral } \\
\text { Singing. }\end{array}$ \\
\hline $\begin{array}{r}\text { PHYSICAL } \\
\text { EXERCISES }\end{array}$ & \multicolumn{3}{|c|}{$\begin{array}{l}\text { Rythmic Drills; Dancing; Games; Plays; Imitation of Normal Activities and Primitive Occupations; Formal Move } \\
\text { ments; Individual Exercises. }\end{array}$} \\
\hline
\end{tabular}



pages; in the latter the work is outlined by telling what is to be done.

This course is, perhaps, as far from perfect as the one that was first examined, but it certainly offers some valuable sugcestions for this investigation. The child demands activity and the lack of it in our present curriculum is responsible for much of the lack of interest and many withdrawals from school. The speyer schodl does not pretend to have worked this out in anything like perfection, but they think they are working in the right direction. There is nothing a child likes so well as doing something that he can see is worth while.

The special attention to physical culture should do much to make the child contented with school life, for hothilht it not only gives a vent to the child's natural desire for activity but it satisfies an ambition that every child has to develop his physical being. Again, using the surrounding occupations as the basis and starting point of the curriculum causes the pupil to see for himself that his school occupations are valuable instead of taking his teacher's word for it that they will some day be of eervice to him.

The Chicago University Elementary School has also broken away from tradition and constructed a course of study on very much the samerprinciples as the one we have just considered. They too have tried to make eduçation real life instead of a preparation fot life. 

64

They emphasize physical culture and doing and the study of surrounding occupations; the excursion is a very prominent feature of the course. Let it not be thought that these experimental schools, if we may call them that, neglect the three $R^{\prime} s$. They are taught and weIl taught but only as means to other ends andiph not as ends in themselves. In the activities of the school the pupil is brought into situations where he needs to know these things and then they are given him in response to a rell felt want; in this way the subjects have a real interest. This is atleast what they are attempting to do at these schools and their investigations certainly offer some help in the solution of this problem.

One other school, the Horace Mann, should be considered briefly. It of necessity is not so radical as the two that have just been considered. The school is not intended to be an experimental school at all but is intended for a model of good teaching. The patrons being wealthy do not care to have their children used in experiments; and as most of the pupils are preparing for college, that must be considered.in the management of the school. In spite of these facts the school has made some departures from the regular curriculum. This is particularly noticable in the time allowed for arithmetic. 

Number of Hours Devoted Weekly to the Various Activities of the Horace Mann School. Table XIX

\begin{tabular}{|c|c|c|c|c|c|c|c|}
\hline Subjects & $\begin{array}{c}G r a d \theta \\
1\end{array}$ & $\begin{array}{c}\text { Grade } \\
\text { II }\end{array}$ & $\operatorname{Grad}_{\text {III }}$ & $\begin{array}{c}\text { Grade } \\
\text { IV }\end{array}$ & $\left.\right|_{\Downarrow} ^{\text {Grade }}$ & $\begin{array}{l}\text { Grade } \\
\text { VI }\end{array}$ & $\begin{array}{c}\text { Grade } \\
\text { VII }\end{array}$ \\
\hline English & 6 & $5-1 / 2$ & $5-2 / 3$ & $5-1 / 2$ & $4-1 / 2$ & $3-1 / 2$ & $4-1 / 2$ \\
\hline $\begin{array}{l}\text { Mathematics } \\
\text { Nature Study }\end{array}$ & 1 & 2 & $2-1 / 2$ & $2-1 / 2$ & 2 & 2 & 2 \\
\hline and Geog. & 1 & $1-1 / 4$ & $2-1 / 2$ & 2 & $2-1 / 2$ & $2-3 / 4$ & $2-1 / 4$ \\
\hline History & & & & 1 & $1-1 / 2$ & $1-3 / 4$ & $1-3 / 4$ \\
\hline Opening Ex. & 1 & 1 & 1 & 1 & 1 & 1 & 1 \\
\hline Gymnasium & $1-1 / 2$ & $1-1 / 2$ & $1-1 / 2$ & $1-1 / 2$ & $1-1 / 2$ & $1-1 / 2$ & $1-1 / 2$ \\
\hline Music & 1 & 1 . & 1 & 1 & 1 & 1 & $\therefore 1 / \%$ \\
\hline Art & $1-1 / 4$ & $1-3 / 4$ & $1-1 / 3$ & $1-1 / 8$ & $1-1 / 4$ & $1-1 / 4$ & $3 / 4$ \\
\hline Manual Tr. & 1 & $1-1 / 3$ & $1-1 / 3$ & $1-1 / 3$ & $1-1 / 2$ & $1-1 / 4$ & $1-1 / 4$ \\
\hline & $2: 40^{\circ}$ & $3: 4$ & $3: 22$ & $3: 26$ & 3135 & $3: 12$ & $3: 6$ \\
\hline
\end{tabular}

By glancing at the above table it will be seen that nature study and geography are given more time than artthmetic, and that gymnasium, ant, and manual training are each given almost as much time. Comparing this with the table for St.Louis it is seen that the position occupied by arithmetic in the two courses is very different. Arithmetic is given much lesstif time and manual trainitg is given much more than in St. Louis--this too in a school that is especially prepating pupils for college. A large part of the ${ }$ "enriching" studies has come from the colleges becaues they did not consider manual training as suitable preparation for college, but now we have a school emphasizing those very studies while preparing for college and oo one has said its 

pupils are not well prepared. If these courses do anything towards solving the problem of keeping pupils in school, they will be an improvement on the old. Let us "test all things and hold fast that which is good".

\section{A Few Conclusions}

It has been clearly shown that a vast army of children are leaving our schools every year with very little training for life and citizenship. The fault lies partly with the pupil and the parent, but much blame also rests with the school. The fact that most of those who leave school are over age and behind with their work indicates that a large part of the withdrawal eithey by inability to do the work or a lack of interest in ths work. It may be taken for granted that much of it is inability, but it is beyond belief that nearly all should be from that cause. Even inability to do the work may not be entirely the pupilis fault, for we may be asking unreasonable things of him--in many cases we are. What can be said of those who quit for lack of interest or what has been called indifference? There are several causes to which the indifference may be attributed; the natural perversity of the child, uninteresting subject matter in the course of study, improper presentation of the subject matter, and what may be called the school machinery.

With the first of these causes we have nothing to do, but in the second there is a large field for inves- 

tigation. We must take the Biological view-point and recognize social efficiency as the tme end of education and revise the curriculum to meet social needs. While we may not entirely endorse the curricula offered by the schools we have noticed, they are certainly working in rich fields and along right lines. It is a well known fact that all knowledge must be based upon personal experience, hence the wider and richer personal experience we can give the child the greater the superstructure we can build thereon. The curriculum should be so worked out that the child will become an actual participator in social activities that are worth his whils, that will make him feel a real need for the three $R^{\prime} s$ and give him a vital interest in thom. As thoughts are useful only as guides to action, a closer union must be worked out between learning and doing.

Some of the statistics seem to indicate that presentation of the subject matter, or the teacher, is a very important factor. It was shown inf one school, at least, that the good teachers lost very few pupils while the poor ones lost many. After all the teacher is the most vital factor in the school as well as in this problem. No matter what the supervisor may put in the curriculum, it is only what the teacher makes it when she presents it to the child; the course of stuay can become a living force only through the quickening touch of the teacher, her personality gives it force. 



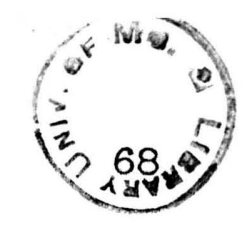

We need most of all more well equipped, well trained teachers who are in sympathy with the children and whoee hearts are in the work.

As to what we have called the school machinery, the crouded school room is perhape the greatest evil. With fifty or even sixty pupils in a room it is impossible to do much but drill work, and unless the teacher is a strong personality discipline becomes galling. This can be remedied only by mori money to emplay more teachers. The system of grading in another part of the school machinery that is undoubtedly responsible for many withdrawals. This might be charged to the account of the teacher as the fault is largely with the administration of the system rather than with the system. If a pupil fails to make the required grade he is compeled to go over the entire year's work and loses a year's time. This frequently true in the city, even, where the classes are close together because the teachers allow them to drift during the year and then cut them back at the end of the term. This would be bad enough if the pupils were always held back justly, but frequently he is held back by a false notion of thoroughness on the part of the teacher. A revision of the idea of thorcughness would do much to symplify the course of study as well as settle the question of promotions. But this brings us back to the teachers--give us more live teachers. 



\section{Bibliography}

Brooks, Stratton D., Ed. Rev., Vol. 26, p. 362 .

Ellis, N.E.A. Report, 1903, p.792.

Gray, Education, Vol. 20, p. 300.

Soldan, F. Louis, Rep. Board of Education, St.Louis $1894-5$, p. 36, 1899-1900, 1903-4.

Woodward, C. M., Rep. Com. of Ed., 1899-1900, p. 1374.

The following bibliography refers to the course of

study.

Dewey, John, Ed. Rev., Vol. 22, pp. 26-49.

N.E.A. Rep. 1901, pp.322-48.

Hanus, P.H., Ed. Rev., Vol. 12, pp. 435-52.

A Modern School.

Harris, W.T., Ed. Rev., Vol. 1l, pp. 323-34.

McMurry, F.M., Ed. Rev., Vol. 27, pp. 478-94.

$$
\text { T. ". Rec., Vol. 3, pp. } 35-61 \text {. }
$$

Soldan, F.Louis, Ed. Rev., Vol. 25, pp.168-81. 









\section{REgEIVEL \\ NoY 291908 \\ UNIV. OF MDA}
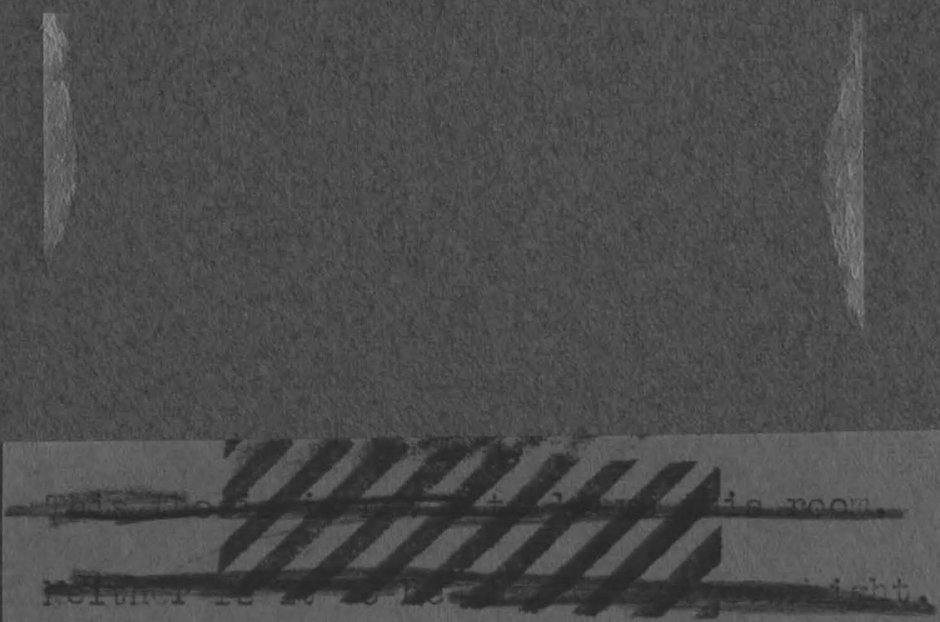


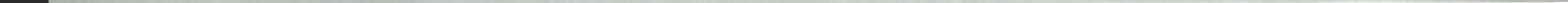

